\title{
The Fallacy of National Studies ${ }^{1}$
}

\author{
Tomasz Kamusella \\ University of St Andrews
}

\begin{abstract}
:
National studies is a broad field of academic pursuits potentially comprised of all the social sciences and humanities, though its typical core is limited to philology, history and ethnography (also known as folklore studies or ethnology). In central Europe (and also in Japan and southeast Asia), where the ethnolinguistic kind of nationalism predominates for building, legitimizing and maintaining nations and their nation-states, national studies are the main intellectual cornerstone of these processes. As such the ideal of dispassionate and disinterested research open to all is abandoned, and scholarship is harnessed into the service of the state-led national idea. The resultant subservience of research to ideology requires adoption of circular logic among proponents and practitioners of national studies the better serve the national interest. Language, history and culture are nationalized and essentialized. The basic assumption of this development is that a given nation's language, history and culture are fully accessible and knowable exclusively to the nation's members. Scholars sticking to this dogma are assured of employment at state-owned and state-approved universities, while those whose research contradicts cherished assumption of the national idea are summarily ostracized in order to bring them into line or make them leave academia.
\end{abstract}

\footnotetext{
${ }^{1}$ This article is an enlarged version of my closing remarks for the conference 'Identities, Categories of Identification, and Identifications Between the Danube, the Alps, and the Adriatic,' held in the National Museum of Contemporary History in Ljubljana, Slovenia on 20-21 April 2017. It was Tamara Scheer, Kaja Širok, Rok Stergar and Marko Zajc who kindly invited me to this event. I also thank Rok Stergar and Catherine Gibson for their patience, valuable advice and helpful comments. Throughout my work on this piece, Rok kindly kept emailing me with interesting references that the better illustrate various methodological points made. As always, Jernej Kosi shared important insights that let me improve the presented argument. An earlier impetus that made me think on national studies was the discussion in the wake of my paper on the a/non-national, titled 'Between National Teleology and Self-Identication' that on the generous invitation of Jan Fellerer, Robert Pyrah and Marius Turda - I delivered at the conference 'Identities In-Between: East-Central Europe, c. 1900-Present,' held on 12-13 September 2016 in Wolfson College, Oxford University, in the framework of the research project 'Subcultures as Integrative Forces in East-Central Europe, 1900-Present,' supported by the Research Councils UK. I am grateful to Jan, Marius and Robert for further comments and suggestions for improvement, alongside their decision to include the article in the postconference volume.
} 
Keywords: circular logic, ethnolinguistic nationalism, history, national studies, philology

\section{Nationalism, Philologists and Peasantry}

In the early modern period in western Europe, a popular idea coalesced that people 'naturally' come in neatly delineated (ethnic) groups. These groups can be discerned through the careful research of their customs and appearance, thus allowing for the supposedly unambiguous and 'scientific' apportioning of all humanity into such 'discoverable' discrete population categories. ${ }^{2}$ Without much comment on this fact, the assumption also entailed the normative belief, which obtains to this day, that an individual can 'naturally' belong only to a single human group of such a type. Perhaps this normative belief stems from the conviction of the Judeo-Christiano-Islamic tradition, which claims that a person can profess only a single religion (at least, at the same time). ${ }^{3}$ The religious strife in western and central Europe that concluded with the Thirty Years' War (1618-1648) reinforced this norm of (serial) monoreligiosity, as succinctly summarized in the 1555 principle of Cuius regio, eius religio (literally, 'Whose realm, his religion'). ${ }^{4}$ It meant that the ruler decided on the single religion (confession) for his realm and all the population needed to follow this dictum, or to leave. ${ }^{5}$ Another consequence of this novel principle was the rise of the sovereign 'territorial state,' which was supposed to be internally homogenous and normatively free of any outside influences. This aforementioned homogeneity meant that the state was reserved for the population of 'the same type,' which at that time meant of the same religion (confession). ${ }^{6}$ At the turn of the $19^{\text {th }}$ century, the

\footnotetext{
${ }^{2}$ Kurze Beschreibung der in Europa befintlichen Völckern und Ihren Aigenschaften ('Völkertafel'). c 1725 [2017]. Wikipedia. https://de.wikipedia.org/wiki/Datei:Völkertafel.jpg. Accessed: May 29, 2017; Leersen, Joep. 2007. National Thought in Europe: A Cultural History. Amsterdam: Amsterdam University Press, pp 25-103.

${ }^{3}$ For instance, in Japan people can simultaneously profess, or rather practice, Buddhist, Christian and Shinto rites (Ama, Toshimaro. 2005. Why are the Japanese Non-religious?: Japanese Spirituality: Being Non-Religious in a Religious Culture [translated from the Japanese by Michihiro Ama]. Lanham MD: University Press of America, p vii; Shinto \& Buddhism. 2017. https://www.japanspecialist.co.uk/travel-tips/shinto-buddhism/. Accessed: Jun 1, 2017).

${ }^{4}$ Cf Jacobson, H F. 1856. Staat und Kirche (pp 420-489). In: Julius Weiske, ed. Rechtslexikon für juristen aller teutschen Staaten (Vol 10). Leipzig: Wigand, p 485.

${ }^{5}$ Obviously, it was a principle of statehood organizations that was not always followed, but was aspired to and implemented wherever practicable. (I thank Jan Fellerer for drawing my attention to this point.)

${ }^{6}$ Neuhaus, Helmut. 2002. Konfessionalisierung und Territorialstaat (pp 343-362). In: Gerhard Müller, Horst Weigelt and Wolfgang Zorn, eds. Handbuch der Geschichte der evangelischen Kirche in Bayern (Vol 1: Von den Anfängen des Christentums bis zum Ende des 18. Jh). St. Ottilien: EOS-Verlag.
} 
Enlightenment quest for discovering and gathering knowledge about the entire (social) world decisively added the category of 'a language' (Einzelsprache) to religion and customs as a necessary and unique trait of each discernible people. ${ }^{7}$

The afore-described ways of 'sorting out' human diversity are sometimes referred to by present-day students of nationalism as 'national thought,' in order to avoid the self-serving phrases 'early nationalism' and 'proto-nationalism' that are actually preferred by nationalists. ${ }^{8}$ But in essence both terms are anachronistic labels applied to preselected earlier (that is, pre-national) intellectual trends, which nationally-minded scholars and national activists found of use for their own national projects, which were mostly developed in the $19^{\text {th }}$ century. ${ }^{9}$ However, scholars and thinkers of the $18^{\text {th }}$ century who were involved in developing and practicing what nowadays is known as 'national thought' did not use the term 'national thought' or 'early nationalism' themselves. In no way did they see their period as 'national'. There were some 'peoples' to be discovered and taken note of, but no nations on the horizon yet.${ }^{10}$ Furthermore, such ideas on discrete peoples as developed by a narrow (almost invariably noble) stratum of male literati had no chance to reach other strata of society, let alone the masses. ${ }^{11}$ In the estates society, birthright, serfdom and illiteracy rigidly separated peasantry (or the vast majority of population) from the demographically tiny nobility. Studies of the national specificity of one people or another, usually focusing on this or that national language, originated in

\footnotetext{
${ }^{7}$ Kamusella, Tomasz. 2004. On the Similarity Between the Concepts of Nation and Language (pp 107-112). Canadian Review of Studies in Nationalism. Vol 31; Kamusella, Tomasz. 2016a. The History of the Normative Opposition of 'Language versus Dialect:' From Its Graeco-Latin Origin to Central Europe's Ethnolinguistic Nation-States (pp 164-188). Colloquia Humanistica. Vol 5. http://ispan.waw.pl/journals/index.php/ch/article/view/ch.2016.011/2342. Accessed: May 29, 2017; Pallas, Peter Simon. 1786-1789. Sravnitel'nye slovari vsech iazykov i narechii / Linguarum totius orbis vocabularia comparative. St Petersburg: Schnoor; Pattanayak, D P. 1981. Multilingualism and Mother-Tongue Education. Delhi: Oxford University Press, pp 5-7.

${ }^{8}$ Cf Bradshaw, Brendan. 2016. 'And So Began the Irish Nation': Nationality, National Consciousness and Nationalism in Pre-modern Ireland. London: Routledge; Hirschi, Caspar. 2012. The Origins of Nationalism: An Alternative History from Ancient Rome to Early Modern Germany. Cambridge: Cambridge University Press; Jensen, Lotte, ed. 2016. The Roots of Nationalism: National Identity Formation in Early Modern Europe, 1600-1815 (Ser: Heritage and Memory Studies, Vol 1). Amsterdam: Amsterdam University Press; Lewicki, Anatol. 1947. Zarys historii Polski (Vol 1: Do r. 1795). London: Obris, p 27. I thank Rok Stergar for pointing out this crucial distinction.

${ }^{9}$ Leerssen 2007, pp 105-171; Sundhaußen, Holm. 1973. Der Einfluß Herderschen Ideen auf die Nationsbildung bei den Völkern der Habsburger Monarchie (Ser: Buchreihe der Südostdeutschen Historischen Kommission, Vol 27). Munich: R Oldenburg Verlag.

${ }^{10}$ Cf Herder, Johann Gottfried. 1800. Outlines of a Philosophy of the History of Man [translated from the German of John Godfrey Herder, by T. Churchill]. London: Printed for J. Johnson, by Luke Hansard.

${ }^{11}$ Cf Stergar, Rok. 2017. Illyrian Autochthonism and the Beginnings of the South Slav Nationalisms in the West Balkans (pp 96-118). In: Antonino De Francesco, ed. In Search of Pre-Classical Antiquity: Rediscovering Ancient Peoples in Mediterranean Europe (19th and 20th c.) (Ser: National Cultivation of Culture, Vol 13). Leiden: Brill.
} 
the $19^{\text {th }}$-century central Europe. ${ }^{12}$ This field of research grew out from two kinds of pursuits. On the one hand, at the turn of modernity philologists discovered vernaculars (illiterate peasantry's speech) as the 'proper' field of their research. In the $19^{\text {th }}$ century these peasant vernaculars came to be understood as discrete national (people's) languages (that is, Einzelsprachen) connected to this or that 'written language' used by an elite for writing, education and administration. In practice philology treated such vernacular languages as metonyms for speech communities, quickly (and almost with no comment) equated with nations to be led by 'their' elites. ${ }^{13}$ It was these elites who invented, imagined nations and their languages into being. ${ }^{14}$

In central Europe during the second half of the 19th century the nation became a new sought-for form of human groupness that was gradually accorded the highest kind of political recognition. This recognition came complete with the right of nations to their own state, especially after the Great War. ${ }^{15}$ Subsequently, the nation was elevated to the hallmark of the future and modernity, as opposed to the region's 'backward' and 'reactionary' empires that were not national in their social or political character and aspirations. ${ }^{16}$ This perceived 'deficiency' of the empires became the more 'visible' during the $19^{\text {th }}$ century, the greater the insistence that the nation must be defined through its own specific vernacular, unshared with any other nation. As a result, for instance, the Austrian Empire's population was largely homogenous in their Catholicism at the beginning of this century. However, three generations later, Einzelsprachen were replacing religion as the main locus of group identity in Austria-Hungary. Descendants of the previously undifferentiated Catholics began to see themselves as now belonging to a variety of ethnolinguistically defined nations tentatively united under Franz

\footnotetext{
12 Leerssen 2007, pp 173-218.

${ }^{13}$ Dominian, Leon. 1917. The Frontiers of Language and Nationality in Europe. New York: Published for the American Geographical Society of New York and Henry Holt; London: Constable, p 342.

${ }^{14}$ Anderson, Benedict. 1983. Imagined Communities: Reflections on the Origin and Spread of Nationalism. London: Verso; Kamusella, Tomasz. 2001. Language as an Instrument of Nationalism in Central Europe (pp 235-252). Nations and Nationalism. Vol 7, No 2; Preston, Dennis R. 1989. Perceptual Dialectology: Nonlinguists' Views of Areal Linguistics (Ser: Topics in Sociolinguistics, Vol 7). Berlin: De Gruyter Mouton.

${ }^{15}$ Cf Hobsbawm, Eric J. 1992. Nations and Nationalism since 1780. Cambridge: Cambridge University Press, p 131; Manela, Erez. 2007. The Wilsonian Moment: Self-Determination and the International Origins of Anticolonial Nationalism. Oxford: Oxford University Press.

${ }^{16}$ Cf Gellner, Ernest. 1983. Nations and Nationalism. Oxford: Blackwell; Masaryk, Tomáš Garrigue. 1936 [1925]. Světová revoluce: Za války a ve válce 1914-1918. Světová revoluce: Za války a ve válce 1914-1918. Prague: Čin a Orbis, pp 505-514. kramerius4.nkp.cz/search/i.jsp?pid=uuid:51ce79a0-1b70-11e3-9319-005056827e51\#monographpage_uuid:b01653f0-3625-11e3-b79f-5ef3fc9bb22f. Accessed: Jul 9, 2017.
} 
Joseph's benign rule. ${ }^{17}$ Obviously, this process was messy, protracted and uneven. As late as the end of World War I, not all inhabitants of Austria-Hungary had seen themselves in national terms. Turning peasants into nationally-conscious individuals required a lot of 'hard work' on the part of nationalist activists (usually stemming from the nobility and burghers, as transformed into a middle class $^{18}$ ), who apart from creating nations and national languages, sought to combat what they termed as 'national indifference.' ${ }^{19}$ The target population (usually peasantry) as a rule of thumb distrusted the novel ideology of nationalism and was reluctant to do their former lords' bidding by joining this or that nation. ${ }^{20}$ Ethnographers and ethnologists (often known as folklorists in central Europe), together with sociologists and anthropologists, were on the forefront of this 'hard national graft,' as the scholarly and political avant-garde of a middle class identifying with a given nation. These academic discovered peasantry, perceived through the national lens as the 'forgotten soul' and the 'true body' of the nation. A craze ensued for collecting peasant songs and customs, which retroactively were fitted to one national language (Einzelsprache) or another, as already identified and endowed with an authoritative dictionary and grammar by peasants' social betters. ${ }^{21}$ Not that peasants enquired about the process understood, supported or identified with proposed languages or nations. ${ }^{22}$ Their identity $^{2}$ remained wedded to their localities, pragmatically anchored in their everyday experience. ${ }^{23}$ It was

\footnotetext{
${ }^{17}$ Cf Judson, Pieter M. 2006. Guardians of the Nation: Activists on the Language Frontiers of Imperial Austria. Cambridge MA: Harvard University Press.

${ }^{18}$ Breuilly, John. 1993. Nationalism and the State. Manchester: Manchester University Press, pp 30-35, 303, 334, 409; Greenfeld, Liah. 1992. Nationalism: Five Roads to Modernity. Cambridge MA: Harvard University Press, pp 145-153, 293-309; Kumar, Ran Vijoy. 1989. Role of the Middle Class in Nationalist Movement, 1912-1947. New Delhi: Commonwealth Publishers; The National Question in Ethiopia: Proletarian Internationalism or Bourgeois Nationalism? 1976. Toronto: Norman Bethune Institute; Watenpaugh, Keith David. 2006. Being Modern in the Middle East: Revolution, Nationalism, Colonialism, and the Arab Middle Class. Princeton NJ: Princeton University Press. I thank Jan Fellerer for this important reminder.

${ }^{19}$ I thank Catherine Gibson for this reminder.

${ }^{20}$ Bjork, James E. 2011. Neither German nor Pole: Catholicism and National Indifference in a Central European Borderland (Ser: Social History, Popular Culture, and Politics in Germany). Ann Arbor MI: University of Michigan Press; Judson 2006; Zahra, Tara. 2011. Kidnapped Souls National Indifference and the Battle for Children in the Bohemian Lands, 1900-1948. Ithaca NY: Cornell University Press.

${ }^{21}$ Cf Grimm, Jacob and Grimm Wilhelm. 1985-1989. Brüder Grimm Volkslieder. Aus der Handschriftensammlung der Universitätsbibliothek Marburg. Marburg: Elwert; Kolberg, Oskar. 1857-1907. Lud. Jego zwyczaje, sposób życia, mowa, podania, przystowia, obrzędy, gusta, zabawy, pieśni, muzyka i tańce. Warsaw: W drukarni Jana Jaworskiego.

${ }^{22}$ Cf Stauter-Halsted, Keely. 2004. The Nation in the Village: The Genesis of Peasant National Identity in Austrian Poland, 1848-1914. Ithaca NY: Cornell University Press.

${ }^{23}$ Kizwalter, Tomasz. 1999. O nowoczesności narodu. Przypadek Polski. Warsaw: Wydanictwo Naukowe Semper, pp 21, 23; Linek, Bernard. 2013. Biskupitz (Biskupice) und Borsigwerk. Soziale Modernisierungswege in Oberschlesien in der zweiten Hälfte des 19. Jahrhunderts (pp 61-77). In: Lutz Budraß. ed. Industrialisierung und Nationalisierung. Fallstudien zur Geschichte des oberschlesischen Industriereviers im 19. und 20. Jahrhundert (Ser: Veröffentlichungen zur Kultur und Geschichte des östlichen Europa, Vol 40). Essen: Klartext; Minnich, Robert G. 1988. Govoriti slovensko - biti Slovenec. Primerjava med vlogo slovenskih verbalnih kod kot nosilcev kolektivne identitete v Kanalski dolini/Val Canale v Italiji, in
} 
hard work to convince them otherwise. National activists had to establish newspapers, educational societies, publishing houses, cooperatives, literary organizations, or schools in order to spread the national message among a target peasant group. More often than not this message in order to take hold had to be coupled with economic incentives that would meet the concerns and needs of peasants in a given village or region. Success at spreading a nationalism among the target group of peasantry was rare, came late if ever, and invariably was judged by national activists (almost invariably from the middle class) as imperfect or only partial. ${ }^{24}$ Furthermore, the activists had to be watchful, so that a peasant groups tentatively secured for 'our nation,' would not be seized by a competing national movement with a more attractive educational or economic offer. ${ }^{25}$

This novel metonymy of language (Einzelsprache) for the nation was set in stone by the equally novel genre of ethnographic (ethnolinguistic) map. It appears that this type of map is indebted to the $18^{\text {th }}$-century 'depiction' of languages (Einzelsprachen) through the 'telegraphic' representation of their writing systems (usually the beginning of the Christian prayer 'Our Father in Heaven') on the maps of the world's continents. ${ }^{26}$ Ethnographic maps that locate peoples (nations) in cartographic

Ziljski dolini/Galital v Avstriji. Trieste: Slovenski raziskovalni inštitut / Istituto sloveno di ricerche / Slovene research institute; Moritsch, Andreas. 1991. Der nationale Differenzierungsprozess am Beispiel ländlicher Gemeinden Südkärnens (pp 44-92). In: Andreas Moritsch, ed. Vom Ethnos zur Nationalität. Der nationale Differenzierungsprozeß am Beispiel ausgewählter Orte in Kärnten und im Burgenland (Ser: Wiener Beiträge zur Geschichte der Neuzeit, Vol 18). Vienna: Verlag für Geschichte und Politik and Munich: R Oldenburg Verlag, pp 49, 89; Stančić, Nikša. 2002. Hrvatska nacija i nacionalizam u 19. i 20. stoljeću (Ser: Homines, tempora, loci). Zagreb: Barbat, pp 81-82; Struve, Kai. 2011. Bauern und ukrainische Nation in der Habsburgermonarchie und im Zarenreich (pp 159173). In: Kappeler, Andreas, ed. Die Ukraine. Prozesse der Nationsbildung. Cologne: Böhlau. https://www.academia.edu/30734129/Bauern_und_ukrainische_Nation_in_der_Habsburgermonarchie_und_im_Zarenreic h. Accessed: Jul 26, 2017.

${ }^{24}$ King, Jeremy. 2005. Budweisers into Czechs and Germans: A Local History of Bohemian Politics, 1848-1948. Princeton NJ: Princeton University Press; Łuczewski, Michał. 2012. Odwieczny naród. Polak i katolik w Żmiqcej (Ser: Monografie Fundacji na Rzecz Nauki Polskiej). Toruń: Wydawnictwo Naukowe Uniwersytetu Mikołaja Kopernika. ${ }^{25}$ Blanke, Richard. 2001. Polish Speaking Germans? Language and National Identity Among the Masurians since 1871 (Ser: Ostmitteleuropa in Vergangenheit und Gegenwart, Vol 24). Cologne: Böhlau; Bonidis, Kyriakos; Palaskas, S and Balabani, K. 2000. Nationalism and Education: The Propagation of the 'Great Idea' of Greek Nationalism Through Education in the European Territories of the Ottoman Empire in the late 19th Century (209-234). In: Nikolaos Terzis, ed. Education in the Balkans: From the Enlightenment to the Founding of the Nation-States (Ser: Education and Pedagogy in Balkan Countries, Vol 2). Thessaloniki: Kyriakidis; Kamusella 2007; Kitromilides, Paschalis M. 1989. 'Imagined Communities' and the Origins of the National Question in the Balkans (pp 149-194). European History Quarterly. Vol 19, No 2; Kamusella, Tomasz; Bjork, James; Wilson, Timothy and Novikov, Anna, eds. 2016. Creating Nationality in Central Europe, 1880-1950: Modernity, Violence and (Be)Longing in Upper Silesia (Ser: Routledge Studies in the History of Russia and Eastern Europe, Vol 25). London: Routledge.

${ }^{26}$ Henselius, Godofredus [Hensel, Gottfried]. 1741. Synopsis Universae Philologiae. Nurmeberg: In commissis apud Herdes Homannionos, maps (NB: The maps of the Americas, Europe, Asia and Africa at the book's end: http://en.wikipedia.org/wiki/File:Hensel_1741_4maps.jpg and http://books.google.co.uk/books?id=Dj4xABSH-

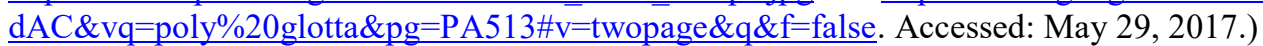


space by depicting the territorial extent of the peoples' languages appeared in the 1820 s and became ubiquitous in the mid- $19^{\text {th }}$ century. ${ }^{27}$ Finally, statistics lent an overpowering aura of 'scientific character' to such maps in the last third of this century. ${ }^{28}$ In 1866, it was proposed that language (Einzelsprache) should be used as the 'objective' marker of nationality. ${ }^{29}$ Shortly thereafter, in 1872 , the delegates attending the Sixth International Statistical Congress at St Petersburg decided that language and nationality (that is, the state of being a member of a nation) are to be included among the essential categories about which population at large $m u s t$ be enquired in state-wide censuses. ${ }^{30}$ Thus, modernizing bureaucrats dethroned religion as the main locus of identity in Europe, and replaced with the novel principle of Cuius regio, eius lingua (literally, 'Whose realm, his language'), despite some serious misgivings, quite strongly felt, for instance, in the Dual Monarchy until the very end if its existence. ${ }^{31}$ This new yardstick of identity was not any less arbitrary than the declaration of this or that faith, though national activists claimed that language was the 'objective' marker of national identity. ${ }^{32}$ For instance, in what today is Belarus, Slavophone-speaking Catholics were classified as 'Poles,' while their Slavic-speaking Orthodox counterparts in the very same village as 'Belarusians' (Engelking 1999). Or Polish intellectuals, during and immediately after World War I, classified the Baltic-speakers in Latvia's region of Latgalia as a separate ethnolinguistic group of Latgalians because they regarded this population's Catholic faith as a stronger marker of distinction than the linguistic closeness between the Latvian and Latgalian languages. ${ }^{33}$

\footnotetext{
${ }^{27}$ Goffart, Walter. 2003. Historical Atlases: The First Three Hundred Years, 1570-1870. Chicago IL: University of Chicago Press, pp 328-329.

${ }^{28}$ Göderle, Wolfgang. 2016b. Administration, Science, and the State: The 1869 Population Census in Austria-Hungary (pp 61-88). Austrian History Yearbook. Vol 47, pp 43-76.

${ }^{29}$ Böckh, Richard. 1866. Die statistische Bedeutung der Volksprache als Kennzeichen der Nationalität (pp 259-402). Zeitschrift für Völkerpsychologie und Sprachwissenschaft. Vol 4.

${ }^{30}$ Report of the Delegates to the International Statistical Congress Held at St Petersburg in August, 1872 (Ser: US House Documents: 43rd Congress, 1st Session, Vol 17, No 289). 1875. Washington: Government Printing Office, pp $37,41$. http://books.google.co.uk/books?id=J-

SxAQAAMAAJ\&printsec $=$ frontcover $\& d q=$ international + statistical + congress $+1872 \&$ hl $=$ en $\&$ sa $=X \& v e d=0$ ahUKEwjVu6 $\underline{\text { mg pfUAhVGKcAKHfeKDMQQ6AEIJDAA\#v=onepage \&q=international } \% 20 \text { statistical } \% 20 \text { congress } \% 201872 \& f=\text { false }}$. Accessed: May 30, 2017.

${ }^{31}$ Cf Die Ergebnisse der Volkszählung vom 31. Dezember 1910 in den im Reichsrate vertretenen Königreichen und Ländern (Vol 1: Die summarischen Ergebnisse der Volkszählung; Ser: Österreichische Statistik, Vol 1, No 1). 1912. Vienna: Bureau der K. u. K. Statistischen Zentralkommission and Gerold in Kommission, pp 58-59.

32 Böckh 1866; Korowicz, Marek Stanisław. 1938. Górnośląska ochrona mniejszości, 1922-1937, na tle stosunków narodowościowych, z 3 mapami (Ser: Pamiętnik Instytutu Śląskiego, Vol 7). Katowice: Wydawnictwa Instytutu Śląskiego (distributed by Nasza Księgarnia, Warsaw).

${ }^{33}$ Gibson, Catherine. 2016. Borderlands Between History and Memory: Latgale's Palimpsestuous Past in Contemporary Latvia (Ser: Politics and Society in the Baltic Sea Region). Tartu: Tartu University Press; Jankowiak, Mirosław. 2016.
} 
In Austria-Hungary in 1880 and in the Russian Empire in 1897, empire-wide censuses were conducted in which the inhabitants were asked about their languages, popularly understood as the 'scientific and objective' indication of their nationalities. ${ }^{34}$ The data generated was used to apportion people to this or that ethnolinguistically defined nation. ${ }^{35}$ As a (largely unintended) result, prospective national movements were given 'hard numerical arguments' about the 'size' and spatial location of postulated nations. This allowed activists to demand political concessions and funds, especially for schooling 'their' nations' youths in and through respective national languages. Ethnolinguistically construed nationalism ceased to be a minority pursuit limited to a small group of noble and bourgeois enthusiasts, and was transformed into a dominant sociopolitical force in the age of mass politics, first heralded by the introduction and spread of full male suffrage: in 1871 in Germany, in 1905 in Russia, and in 1907 in the 'Austrian half' of Austria-Hungary. ${ }^{36}$

Funkcjonowanie języka łatgalskiego w sytuacji wielokulturowości i wielojęzyczności (pp 273-296). Zeszyty Łużyckie. Vol 50 .

${ }^{34}$ The realities of the censuses were messier than the statement may suggest. In the Dual Monarchy de facto two separate censuses were conducted in the Austrian and Hungarian 'halves' of Austria-Hungary. In the latter census, individuals were queried about more than a single language, which on the contrary was the norm in Cisleithania (Fellerer, Jan. 2005. Mehrsprachigkeit im galizischen Verwaltungswesen (1772-1914). Eine historisch-soziolinguistische Studie zum Polnischen und Ruthenischen (Ukrainischen) (Ser: Bausteine zur Slavischen Philologie und Kulturgeschichte, Series A: Neue Folge, Slavistische Forschungen, Vol 46). Cologne: Böhlau; Gal, Susan. 2011. Polyglot Nationalism: Alternative Perspectives on Language in $19^{\text {th }}$ Century Hungary (pp 31-54). Langage et société. No 2 (136), p 42; Varga, Balint. 2014. Multilingualism in Urban Hungary, 1880-1910 (pp 965-980). Nationalities Papers. Vol 42. No 6, p 967). I thank Rok Stergar and Robert Pyrah for this important reminder. Furthermore, as Jan Fellerer kindly remarked, the AustroHungarian authorities' official position was that declaring a language in a census was not indicative of nationality. ${ }^{35} \mathrm{Cf}$ Ethnographic Maps of the 19th Century. 2017. http://www.lib.uchicago.edu/e/collections/maps/ethnographic/. Accessed: May 29, 2017; Gibson, Catherine. 2017. 19th Century Ethnographic Maps of the North-West Russian Empire: Estonia, Latvia, Lithuania, Belarus, Poland. historicalbalticmaps.com/project-type/ethnographic-maps/. Accessed: May 29, 2017; Göderle 2016a; Göderle, Wolfgang. 2016b. Administration, Science, and the State: The 1869 Population Census in Austria-Hungary (pp 61-88). Austrian History Yearbook. Vol 47. However, as Jan Fellerer cautions, the AustroHungarian authorities consistently denied that the census rubric with the question about language (Umgangsprache) was indicative of respondents' nationality (or the fact of belonging to an ethnolinguistically defined nation).

${ }^{36} \mathrm{Cf}$ Cornwall, Mark. 2002. The Last Years of Austria-Hungary: A Multi-national Experiment in Early Twentieth-century Europe. Exeter: University of Exeter Press, p 85; Hroch, Miroslav. 1985. Social Preconditions of National Revival in Europe: A Comparative Analysis of the Social Composition of Patriotic Groups Among the Smaller European Nations. Cambridge: Cambridge University Press; Thompson Manning, Roberta. 1982. The Zemstvo and Politics, 1864-1914 (pp 133-176). In: Terence Emmons and Wayne S. Vucinich, eds. The Zemstvo in Russia: An Experiment in Local SelfGovernment. Cambridge: Cambridge University Press, p 151; Woolf, Alex. 2009. Systems of Government Democracy. London: Evans, p 117. 
Initially amateur and private philologists put themselves to the task of endowing their (usually native) languages with 'scientific' dictionaries and grammars, first using their own leisure and money. ${ }^{37}$ But later scholarly foundations and university departments were established for researching and standardizing a growing number of officially recognized languages (Einzelsprachen). ${ }^{38}$ These institutions could gradually tap into funds made available by multiethnic empires, which wished to either placate emerging ethnolinguistic national movements or periodically suppressed them by banning the use of some national languages or scripts. ${ }^{39}$ Meanwhile folklorists were busy collecting a given peasantry's songs and customs, which they saw as equal in quality to or even transcending the ancient Homeric tradition. ${ }^{40}$ Both groups of scholars soon propounded that the language of an elite (nobility) was 'impure,' due to 'foreign' influences, usually from Latin, French or German. Slavic languages were to be 'true' to their Slavic character, while Germanic ones to their Germanic 'soul.' Hence, 'ugly foreign Gallicisms, Germanisms, or Slavicisms' were replaced with neologisms coined entirely from 'native' word roots or borrowed form a 'kindred' language (cf. Davies and Langer 2005; Wexler 1974). In this way, for example, standard Czech had been 'purged' of German(ic) words by the turn of the $20^{\text {th }}$ century, while standard Romanian was infused with numerous Italian and French linguistic loans from the 1830 s through the interwar period. ${ }^{41}$

An ethnically correlated peasantry's speech extolled as an epitome of the 'pure' national language actually posed the pesky problem of easily observed spatial variability. The single 'peasant language,' in breach of the national dogma of uniform homogeneity, somehow differed from village to village,

\footnotetext{
${ }^{37}$ Cf Considine, John. 2008. Dictionaries in Early Modern Europe: Lexicography and the Making of Heritage. Cambridge: Cambridge University Press; Considine, John. 2017. Small Dictionaries and Curiosity: Lexicography and Fieldwork in Post-Medieval Europe. Oxford: Oxford University Press; Stefanović, Vuk / Stephansohn, Wolf / Lupi, Stephani F [=Karadžić, Vuk]. 1818. Srpski rječnik isšolkovan njemačkim i latinskim riječma / Serbisch-DeutschLateinisches Wörterbuch / Lexicon Serbiou-Germanico-Latinum. Vienna: Gedruckt bei den P.P. Armeniern. ${ }^{38}$ Cf Considine, John. 2014. Academy Dictionaries 1600-1800. Cambridge: Cambridge University Press; Jungmann, Josef. 1835-1839. Slownjk česko-německý (5 vols). Prague: Pomocj Českého Museum; Linde, Samuel. 1854-1860. Stownik języka polskiego przez M. Samuela Bogumiła Linde. Lwów [Lviv]: W Drukarni Zakładu Ossolińskich. ${ }^{39}$ Cf Judson, Pieter M. 2016. The Habsburg Empire: A New History. Cambridge MA: Harvard University Press, pp 269332; Rodkiewicz, Witold. 1998. Russian Nationality Policy in the Western Provinces of the Empire (1863-1905). Lublin: Scientific Society of Lublin; Thaden, Edward, ed. 1981. Russification in the Baltic Provinces and Finland, 1855-1914. Princeton NJ: Princeton University Press.

${ }^{40}$ Cf Kadare, Ismail. 1997. The File on H. New York: Arcade Publishing.

${ }^{41}$ Close, Elizabeth. 1974. The Development of Modern Rumanian: Linguistic Theory and Practice in Muntenia 1821-1838 (Ser: Oxford Modern Languages and Literature Monographs). Oxford: Oxford University Press; Morariu, Leca. 1937. Maiorescu şi neologismul. Cernăuți (Chernivtsi): Tiparul Glasul Bucovinci; Thomas, George. 1996. Towards a History of Modern Czech Purism: The Problem of Covert Germanisms (pp 401-420). The Slavonic and East European Review. Vol 74, No 3.
} 
from region to region, and was not at all free of 'foreign impurities,' either. ${ }^{42}$ For instance, the speech of the 'Romanian' peasant was replete with numerous (lexical, syntactic and grammatical) Slavicisms (irrespective of a region), especially due to the centuries-long use of Church Slavonic as official and liturgical language. ${ }^{43}$ This problem was 'explained away' by nobles' long-century oppression of peasants through the system of serfdom. As a result, the supposedly pristine culture and language of peasantry were corrupted, and the putative early medieval or even ancient nation was thus fragmented, because serfs were not permitted to leave their villages or parishes. ${ }^{44}$ Simultaneously, nobility 'unjustifiably' separated themselves from their ethnically kin 'peasant brethren' ('betrayed the people') by adopting a 'foreign language' (Latin, French or German), by allowing a succession of (nationally) 'foreign' monarchs to assume the throne of the (national) kingdom, and by marrying foreign nobles.

This corruption - in the novel nationalist interpretation of the past and the present moment - almost destroyed the nation and its language, which nearly 'died.' But no, a ray of hope remained, as 'in reality' both nation and language just 'fell deeply asleep.' National activists perceived their task as to 'awaken' 45 the nation from its heavy slumber, aided in this difficult task by philologists and

\footnotetext{
${ }^{42}$ Cf Weber, Eugen. 1976. Peasants into Frenchmen: The Modernization of Rural France, 1870-1914. Stanford CA: Stanford University Press.

${ }^{43}$ Cf Mârza, Radu. 2008. The History of Romanian Slavic Studies: From the Beginnings until the First World War [translated from the Romanian By Leonard Ciocan]. Cluj-Napoca: Romanian Academy and Center for Transylvanian Studies; Petrucci, Peter R. 1999. Slavic Features in the History of Rumanian (Ser: LINCOM Studies in Romance Linguistics, Vol 8). Munich: LINCOM Europa.

${ }^{44}$ Cf Bogdański, Henryk. 1980. Dziennik podróży z lat 1826 i 1827 (Wiedeń-Bratysława-Budapeszt-Zagrzeb-RijekaTriest-Lublana-Budapeszt-Przemyśl) (edited by Józef Długosz and Józef Adam Kosiński). Cracow: Wydawnictwo Literackie, $\mathrm{p} 156$.

${ }^{45}$ In inverted commas I give usages and concepts typical of the lexicon of ethnolinguistic nationalisms in central Europe, and employed to this day for narrating and discussing the history of this region in central Europe's national master narratives, as employed in school and popular discourse. This discourse originated in the $19^{\text {th }}$ century, and in its framework nations are believed to be very old or eternal. They enjoyed their presumed 'golden age' somewhen in the $9^{\text {th }}$ or $10^{\text {th }}$ century, but afterward 'fell asleep' when multiethnic dynastic empires were established across central Europe governed through the 'foreign language' of Latin, French or German to the perceived detriment of the national language. Language seen as the nation's 'spirit' (essence) had to be 're-born' (that is, standardized for written and publishing purposes) in order to effect the somnolent nation's 'reawakening' (in reality, the creation of a nation on an ethnolinguistic basis). Cf Bobryk, Adam. 2006. Odrodzenie narodowe Polaków w Republice Litewskiej 1987-1997. Toruń: Dom Wydawniczy Duet; Cetnarowicz, Antoni. 2010. Odrodzenie narodowe w Istrii w latach 1860-1907 (Ser: Studia z Historii XIX wieku, Vol 1). Cracow: Historia Iagellonica; Šmahel, František. 1971. Idea národa v husitských Čechách. České Budějovice: Růže; Trapl, Miroslav. 1977. České národni obrozeni na Moravě v době prededbreznové a v revolučních letech 1848-1849. Brno: Blok.
} 
folklorists, alongside nationally-minded historians and cartographers. ${ }^{46}$ By that time the ideas of ethnolinguistic nationalism had become so deeply and unreflectively internalized in the thinking of the aforementioned activists that most genuinely believed in what they were saying. ${ }^{47}$ When the ancient (or medieval) state of the nation was successfully re-established, peasants freed from the proverbial 'chains of serfdom,' and nobles gave up their elevated status (alongside foreign languages) and rejected foreign rulers in the name of national love with their peasant brethren, at long last it was time for the 're-purified' (proper, correct) national language to be taught to all (peasant and noble sons and daughters) in compulsory elementary schools. Because the national language was made the sole medium of instruction and the main subject of study in such schools, in the span of two to three generations it became the preferred basis of national unity. ${ }^{48}$ The nation's members began communicating with one another and imagining 'their' nation into being from generation to generation exclusively through the medium of the nation's 'own' national language. On the other hand, the deepening monolingualism in the standard version of the nation's language increasingly isolated it from other nations and their members, now posed as 'foreign.'

Not that it was a smooth process. National activists clamoring for different national projects often disagreed where the language of one nation stopped and another nation's language began. This was an exercise in the proverbial forcing of a square peg into a round hole. They sought to identify clearcut borders of their national language in line with the Western concept of a discrete and countable language (Einzelsprache). However, the linguistic reality on the ground more often than not was continuous in its character, that is, changing from village to village, from region to region, with no cliff?? of difference that would indisputably mark the end of one language and the beginning of another. ${ }^{49}$ In such a case activists enamored of the concept of Einzelsprache had no choice but to

\footnotetext{
${ }^{46}$ Cf Baár, Monika. 2013. Historians and Nationalism: East-Central Europe in the Nineteenth Century (Ser: Oxford Historical Monographs). Oxford: Oxford University Press.

${ }^{47}$ Cf Kollár, Jan. 1832. Sláwy Dcera. Lyricko-epická báseň w pěti zpěwjch. Pest: Trattner a Károli. http://books.google.co.uk/books?id=k8gGAAAAQAAJ\&printsec=frontcover\&dq=Sláwy+dcera\&hl=en\&sa=X\&ved=0ah UKEwjcuoui9JXUAhWMIcAKHcbnAHIQ6AEIJDAA\#v=onepage\&q=Sláwy dcera\&f=false. Accessed: May 29, 2017; Preschern, Franz [=Prešeren, France]. 1833. Sängers Klage. Illyrisches Blatt. Vol 7, No 24. 15 Jun.

${ }^{48}$ Cf Łuczewski 2012.

${ }^{49}$ Cf Kloss, Heinz. 1967. 'Abstand Languages' and 'Ausbau Languages' (pp 29-41). Anthropological Linguistics. Vol 9 , No 7; Trudgill, Peter. 2003. A Glossary of Sociolinguistics. Edinburgh: Edinburgh University Press, pp 35-36.
} 
arbitrarily decide where such a border was to be put, if they wanted to continue constructing their nation on a linguistic basis. ${ }^{50}$

For instance, in the Habsburg Monarchy Croatian nationalists frequently denied the existence of any Slovenian nation, referring to them as 'Alpine Croats,' whose language was 'corrupted,' due to 'centuries-long Germanization', ${ }^{51}$ while a few Slovenian activists, already in the first half of the $19^{\text {th }}$ century proposed that all speakers of the Kajkavian dialect (today's northwestern Croatia with the country's capital of Zagreb) were Slovenes. ${ }^{52}$ Beginning in the mid- $19^{\text {th }}$ century Serbian nationalists developed a theory that all speakers of the Štokavian dialect (now shared, at the level of official language, by the Bosnians, Croats, Montenegrins and Serbs) are Serbs, despite any religious differences or the confessionally-coordinated use of different scripts for writing. ${ }^{53}$ Croatian nationalists replied in kind, claiming that all South Slavs (with the tentative exception of the Bulgarians) were Croats and spoke Croatian. ${ }^{54}$ Likewise, until the end of the existence of the Russian Empire, Belarusians and Ukrainians - officially known in Russian as 'White Russians' and 'Little Russians' - were seen to be 'junior branches' of the '(Great) Russian' nation, because they 'stemmed directly' from the medieval polity of Rus'. In this case it was 'centuries-long Polonization' that corrupted Belarusians' and Ukrainians' once 'pristine Russian language. ${ }^{55}$ Of course, no one cared to

\footnotetext{
${ }^{50}$ Cf Zajc, Marko. 2008. Gdje slovensko prestaje, a hrvatsko počinje. Slovensko-hrvatska granica u 19. i početkom 20. stoljeća (translated from the Slovenian into Croatian by Anita Peti-Stantić, Sanja Slukan and Miroslav Gradečak). Zagreb: Srednja Europa.

${ }^{51}$ Petranović, Branko. 2002. The Yugoslav Experience of Serbian National Integration (Ser: East European Monographs, Vol 586). Boulder CO: East European Monographs (distributed by Columbia University Press, New York), p 23; Zajc 2008, pp 146, 205-207, 237-267.

${ }^{52}$ Greenberg, Marc L. 2011. The Illyrian Movement: A Croatian Vision of South Slavic Unity (pp 364-380). In: Joshua Fishman and Ofelia García, eds. Handbook of Language and Ethnic Identity (Vol 2: The Success-Failure Continuum in Language and Ethnic Identity Efforts). Oxford: Oxford University Press, p 372; Merchiers, Ingrid. 2007. Cultural Nationalism in the South Slav Habsburg Lands in the Early Nineteenth Century: The Scholary Network of Jernej Kopitar (1780-1844) (Ser: Slavistische Beiträge, Vol 455). Munich: Sagner, p 320.

${ }^{53}$ Greenberg, Robert D. 2004. Language and Identity in the Balkans: Serbo-Croatian and Its Disintegration. Oxford: Oxford University Press, p 68; White, George W. 2000. Nationalism and Territory: Constructing Group Identity in Southeastern Europe (Ser: Geographical Perspectives on the Human Past). Lanham MD: Rowman \& Littlefield, p 182. ${ }^{54}$ Bartulin, Nevenko. 2014. The Racial Idea in the Independent State of Croatia: Origins and Theory (Ser: Central and Eastern Europe: Regional Perspectives in Global Context, Vol 4). Leiden: Brill, p 36; Markus, Tomislav. 2010. The Serbian Question in Croatian Politics, 1848-1918 (pp 165-188). Review of Croatian History. Vol 6, No 1, p 169. hrcak.srce.hr/file/100788. Accessed: Jul 26, 2017.

${ }^{55}$ Cf Hrushevsky, Michael. 1965. The Traditional Scheme of 'Russian' History and the Problem of a Rational Organization of the History of the East Slavs (Ser: Slavistica). Winnipeg: Ukrainian Free Academy of Sciences and Ukrainian Canadian University Students' Union; Kohut, Zenon E. 1994. History as a Battleground: Russian-Ukrainian Relations and Historical Consciousness in Contemporary Ukraine (pp123-146). In: S Frederick Starr, ed. The Legacy of History in Russia and the New States of Eurasia (Ser: International Politics of Eurasia, Vol 1). Armonk NY: M E Sharpe,
} 
enquire the target populations regarding their views about their identity and ideals of political groupness. Nationalists always know better what the 'correct identity' of the 'nationally unconscious' population is, or should be. ${ }^{56}$

\section{Educating the Nation}

The molding of nobles (and burghers) together with peasantry on the basis of their postulated 'common national language' that somehow needs to be taught to all and sundry in school, is central Europe's typical paradigm of creating 'national history' through philology, that is, through language creation and engineering. ${ }^{57}$ This exercise was repeated with minor alterations in the case of the Norwegians, Latvians, Poles, Slovaks, Croats, Macedonians or Greeks, namely, in the case of the region's ethnolinguistic nations, which achieved the goal of their own unshared nation-states. The national master narrative is developed, maintained and transmitted by national philology and history. ${ }^{58}$ The latter is represented by the History of Germany, History of Poland, History of Slovenia or History of Bulgaria, while names of the nationally-inflected philologies are coined from the Latin or current names of nations, for instance, Germanistik for the German nation, Polonistyka for the Polish nation, Slovenistika for the Slovenian nation, or Българистика (Balgaristika) for the Bulgarian nation. ${ }^{59}$ Both national history and philology are the leading departments of the social sciences and humanities at national universities in any central European national polity, alongside departments of

\footnotetext{
p 125. In the aforementioned publication by Mykhailo Hrushevsky (Hrushevs'kyi, 1866-1934), this Ukrainian historian analyzed and criticized this preferred Russian interpretation of Ukrainian and Belarusian history. (I thank Catherine Gibson for reminding me to make this point clear.)

${ }^{56}$ Cf Benisz, Adam. 1930. Górny Śląsk w walce o polskość. Katowice: "Rozwój", pp 140-141; Goble, Luke J. 2007 [PhD dissertation]. Indians and the National Unconscious: Discourses of Nationalism and Democracy in the United States and Bolivia, 1780-1850. Buffalo NY: State University of New York at Buffalo; Mróz, Maciej. 2003. Katolicyzm na pograniczu. Kościół katolicki wobec kwestii ukraińskiej i białoruskiej w Polsce w latach 1918-1925. Toruń: Wydawnictwo Adam Marszałek.

${ }^{57}$ Cf Bonfiglio, Thomas Paul. 2010. Mother Tongues and Nations: The Invention of the Native Speaker (Ser: Trends in Linguistics, Studies and Monographs). Berlin: Walter de Gruyter.

${ }^{58}$ Cf Mackridge, Peter. 2010. Language and National Identity in Greece, 1766-1976. Oxford: Oxford University Press.

${ }^{59}$ Interestingly, no nationally-inflected university departments of philology were created for the Austrians or the (Germanophone) Swiss. In both countries relevant university departments are of Germanistik, rather than of Austriazistik (Austrianistik) or Helvetistik. On the other hand, although the object of the study is almost the same, alongside Българистика (Balgaristika) the parallel discipline of Македонистика (Makedonistika) had to be founded in Macedonia. It is so, because in the former case there is no officially recognized Austrian or Swiss language, while in the latter Macedonian is recognized as language in its own right, that is, separate from Bulgarian. This example shows where in Europe the normative hold of ethnolinguistic nationalism is at its strongest, and where it is less observed.
} 
ethnology (folklore studies ${ }^{60}$ ) (nowadays frequently transformed into less ideologized departments of anthropology). ${ }^{61}$

Graduates of these departments become teachers in schools, transmitting the 'correct' national message and its very medium to the successive generations of citizens in this or that nation-state. The goal is 'to develop and strengthen the feeling of national belonging' ${ }^{62}$ The national message is posed as the 'historic truth.' If that is questioned by 'schoolchildren who are too much inquisitive for their own good,' or by pesky foreigners, this national truth must be defended as much as one's own country, because 'the nation's honor is at stake.' If an argument posed by an 'anti-nationalist' or 'national agnostic' cannot be logically refuted, the last line of national defence is to say that foreigners with inherently imperfect knowledge of 'our' language and history 'by nature' are unable to see in full 'our national truth.' A 'solution' in the case of 'in-house doubters' is easier: unless they make sure to see the national light, they will fail their exams and will be barred from attending secondary school, let alone university. A more difficult problem is posed by university graduates who belatedly lost faith in 'their' nation. At their disposal they have a wide array of intellectual instruments and methods to debunk cherished national myths. However, peer pressure and rituals of public naming and shaming work wonders. ${ }^{63}$ Should the 'culprit' persist in his wayward ways, the measures may be combined with a formal or informal (but strictly observed) ban from the profession for which the person concerned earned qualifications, followed by forced relocation to the countryside for the most obstinate detractors. ${ }^{64}$

\footnotetext{
${ }^{60} \mathrm{Cf}$ Baycroft, Timothy and Hopkin, David M, eds. 2012. Folklore and Nationalism in Europe During the Long Nineteenth Century (Ser: National Cultivation of Culture, Vol 4). Leiden: Brill.

${ }^{61}$ Cf Baár 2013; Daskalov, Roumen et al, eds. 2013-2017. Entangled Histories of the Balkans (4 vols) (Ser: Balkan Studies Library, Vols 9, 12, 16, 18.). Leiden: Brill; Kamusella, Tomasz. 2010. Philologists: Scholars or, Perhaps, Politicians? Review: D L Hoyt and K Oslund, eds. The Study of Language and the Politics of Community in Global Context (pp 327-334). Polish Sociological Review. No 3 (171); Wawn, Andrew, eds 2007. Constructing Nations, Reconstructing Myth: Essays in Honour of T A Shippey (Ser: Making the Middle Ages, Vol 9). Turnhout: Brepols. ${ }^{62}$ Cf Podstawa programowa - Historia - klasy IV-VIII. 2017. Warsaw: Ministerstwo Edukacji Narodowej, p 1. https://men.gov.pl/wp-content/.../11/podstawa-programowa-historia-klasy-iv-viii.pdf. Accessed: May 26, 2017. ${ }^{63}$ Cf Grdina, Igor. 2016. Tajna zgodovina. Reporter. 22 May. http://twitter.com/revijareporter/status/734621095362433024. Accessed: Jun 12, 2016; Kochman, Stanisław. 2004. On nie reprezentuje uniwersytetu (p 14). Nowa Trybuna Opolska. 14 May; Senft, Stanisław and Drobek, Wiesław. 2004. W sprawie wypowiedzi prasowych dr Tomasza Kamuselli. Ślask Opolski. No 2 (51); Szczepanik, Marek. 2004. Wizje pana doktora. Rzeczpospolita. No 107, 8 May. archiwum.rp.pl/artykul/486002-Wizje-pana-doktora.html. Accessed: Jul 26, 2017.

${ }^{64}$ Stral'tsoŭ, B V. 1967. V bor'be za Sovetskuiu vlast'. Minsk: Beralus'; Wilczy bilet. 2017. Wikipedia. http://pl.wikipedia.org/wiki/Wilczy bilet. Accessed: May 31, 2017.
} 
This pattern of construing about and instilling the national message and its medium in the successive generations of students is also followed in Japan, where ethnolinguistic nationalism was borrowed wholesale from Germany in the late $1870 \mathrm{~s}^{65}$ and subsequently grafted on the local tradition of isolationism and the popular feeling of civilizational superiority toward foreigners. ${ }^{66}$ But ethnolinguistic nationalism got hold among the Japanese as late as the $1920 \mathrm{~s},{ }^{67}$ leading a decade later to the creation of a monolithic standard Japanese language at the expense of suppressing previously huge linguistic and regional differences. ${ }^{68}$ The success of this program of ethnolingtuistic nationalization (combined with the loss of the empire in 1945) produced, in the 1960s, a national dogma that Japan has been an ethnolinguistically homogenous polity for millennia. ${ }^{69}$ This widely popular belief is often accepted at the face value also outside Japan, and mirrors the equally fallacious conviction that France has been an ethnolinguistically homogenous polity for centuries. ${ }^{70}$

In Japan the division between national insiders and 'ignorant foreigners' (外人 gaijin, literally 'outside person,' but often employed to mean 'overseas devil') is even more pronounced. ${ }^{71}$ When Japanese learn their Japanese language at school it is known as 国語 Kokugo (national language), while the subject of study for foreigners who want to learn this language is referred to as 日本語 Nihongo ([limited, simplified] Japanese). The assumption is that non-Japanese are inherently unable to fully master the Japanese language (Kokugo), so they are compelled to settle for the language's insipid reflection, namely, Nihongo. ${ }^{72}$ A racist 'scientific' explanation of this 'fact,' as developed during the first half of the $20^{\text {th }}$ century, proclaims that the Japanese brain is biologically different ('better') from the ('inferior') brains of foreigners. Only the Japanese brain can 'get' all the intricacies

\footnotetext{
${ }^{65}$ Martin, Bernd. 1990. The German Role in the Modernization of Japan: The Pitfall of Blind Acculturation [translated from the German by Peter Wetzler] (pp 77-88). Oriens Extremus. Vol 33, No 1.

${ }^{66}$ Farkas, Ildikó. 2015. Cultural Identity, Nation Building, Modernization: Defining Identity in Japan and East-Central Europe in the $18^{\text {th }}$ and Early $19^{\text {th }}$ Century (pp 51-86). In: Melinda Papp (Pappová), ed. Encounters with Japan: Japanese studies in the Visegrad Four Countries. Budapest: Eötvös University Press (ELTE Faculty of Humanities).

${ }^{67}$ Lie, John. 2001. Multiethnic Japan. Cambridge MA: Harvard University Press, pp 119-121.

${ }^{68}$ Heinrich, Patrick. 2012. The Making of Monolingual Japan: Language Ideology and Japanese Modernity. Bristol: Multilingual Matters; Lie 2001, p 105.

${ }^{69}$ Lie 2001, p 125.

${ }^{70} \mathrm{Cf}$ Weber 1976.

${ }^{71}$ Cf Sieroszewski, Wacław. 1957. Zamorski diabeł. Jan-Gui-Tzy. Warsaw: Ludowa Spółdzielnia Wydawnicza.

${ }^{72}$ Yeounsuk, Lee. 2010. The Ideology of Kokugo Nationalizing Language in Modern Japan [translated from the Japanese by Maki Hirano Hubbard]. Honolulu HI: University of Hawai'i Press.
} 
of Japanese language and culture. Hence, the popular Japanese belief is that foreigners are 'biologically' unable to achieve a native-level command of this language. ${ }^{73}$

Likewise, the nationalist distinction between Kokugo and Nihongo is duly reflected at universities. Future school teachers of the Japanese language for the country's national schools study at the departments of 国語学 Kokugo-gaku. On the other hand, those who want to teach this language to foreigners study in the departments of 日本語学 Nihongo-gaku. It is akin to the ELT (English Language Training) specialization that produces teachers of English as a second language. (The salient difference is that graduates of departments of English and ELT study the very same English language, not its two different varieties, one civilizationally and culturally 'higher' and the other 'lower.') On the contrary, Kokugo-gaku is an exact counterpart of central Europe's Germanistik or Polonistyka, that is, nationally-inflected philology. Graduates of departments of Kokugo-gaku maintain the national language and make sure that its proper' knowledge continues to be spread from one generation to another.

\section{The Circular Logic of Nationalism}

The logic of such national studies focused on language as the mystic essence of nationhood is inherently circular: A is B, because B is A. Foreigners (A) do not understand our national culture (B). Why is it so? Because our language and culture (B) are so sublime and inherently specific only to us. Hence, foreigners (A) with their biologically limited brains are inherently unable to master our language, which is the sole gateway to the 'transcendental truth' about our nation. Or: our language (A) is the best in the world (B), because all other languages (B) are naturally inferior to our language (A). Or: our nation-state is ancient, at least one millennium old (A), though it was established only in 1918 (B) (as in the case of Poland). It was evil foreign powers (B) that for nine centuries suppressed our state, unjustifiably incorporated into this 'alien and monstrous' empire (as, for instance, the

\footnotetext{
${ }^{73}$ McVeigh, Brian J. 2006. Nationalisms of Japan: Managing and Mystifying Identity. Lanham MD: Rowman \& Littlefield, p 156; Sugimoto, Yoshio and Mouer, Ross. 2009. Cross-Currents in the Study of Japanese Society (pp 1-38). Yoshio Sugimoto and Ross Mouer, ed. Constructs For Understanding Japan (Ser: Japanese Studies). Abingdon: Routledge, pp 21-22.
} 
Slovak or Slovenian national master narrative proposes). ${ }^{74} \mathrm{Or}$, in line with ethnolinguistic nationalism's equation of language, nation and state: our national language was standardized (that is, created and endowed with a name) in the late $19^{\text {th }}$ century (A), but our ancestors had already spoken it a millennium ago (though this language had not then existed as a discernible entity, and its name, grammar and dictionaries had not been yet invented) (B). Hence, the (unsubstantiated) postulate of the existence of our language in the distant past (A) 'proves' the existence of our nation (that is, hypothetical speakers of the language in question) at least a millennium ago (B). Ergo, the 'proper' territory of our nation-state founded in 1991 (A) (as in the case of Slovenia), is the same territory that was inhabited by this language's speakers in the late Middle Ages (B). However, it is national historians and philologists of the present day (A) who decide who and where spoke the national language half a millennium ago, or at least three centuries prior to its creation (B). Logical paradoxes of this kind multiply. ${ }^{75}$

Obviously, an opening of the now largely circular discussion is possible, if conducted in line with the facts on the ground as reflected in available sources. But this means an acknowledgement that the concept of nation is a Western creation, which first appeared in the $18^{\text {th }}$ century. Afterward populations of non-national kingdoms (for instance, France) and ethnolinguistically defined-cumbeing-created speech communities (for example, German-speakers) were overhauled into nations with the use of political decisions. In turn, these decisions were implemented through bureaucracy, universal elementary education and the ubiquitous press ('print capitalism'). ${ }^{76}$ Likewise, the concept of 'a countable and discrete language' (Einzelsprache) is a western (Graeco-Roman) invention, dating back to around the First century $\mathrm{CE},{ }^{77}$ which in the age of high imperialism was spread all over the

\footnotetext{
${ }^{74}$ Some central European historians are critical of and debunk with their research this anachronistic paradigm of constructing national master narrative that endows a present-day nation-state with a specious 'millennium-long history' (cf. De Francesco, Antonino, ed. 2017. In Search of Pre-Classical Antiquity: Rediscovering Ancient Peoples in Mediterranean Europe (19th and 20th c.) (Ser: National Cultivation of Culture, Vol 13). Leiden: Brill; Stih, Peter. 2010. The Middle Ages Between the Eastern Alps and the Northern Adriatic: Select Papers on Slovene Historiography and Medieval History (Ser: East Central and Eastern Europe in the Middle Ages, 450-1450, Vol 11). Leiden: Brill). But the discussion has not percolated into the mainstream intellectual discourse in the region, let alone into history textbooks. ${ }^{75}$ I thank Jernej Kosi for reminding me about the circular character of ideas that underpin the practices of ethnolinguistic nationalism. He presented and analyzed this kind of national thought theory in action on the example of Slovenian nationalism in his detailed monograph on this subject (Kosi, Jernej. 2013. Kako je nastal slovenski narod. Začetki slovenskega nacionalnega gibanja v prvi polovici 19. stoletja (Ser: Zbirka Naprej!). Ljubljana: Sophia).

${ }^{76}$ Anderson 1983, pp 43-45.

${ }^{77}$ Kamusella 2016a; Makoni, Sinfree and Pennycook, Alastair. 2007. Disinventing and Reconstituting Languages (pp 1 41). In: Sinfree Makoni and Alastair Pennycook, eds. Disinventing and Reconstituting Languages (Ser: Bilingual
} 
world. ${ }^{78}$ The Reformation brought about the replacement of Latin as the sole 'official' written language of western Christianity with vernaculars, shaped as written languages on the model of Latin. The model was none other than that of 'a countable and discrete language' (Einzelsprache). Since the turn of the $16^{\text {th }}$ century, this model allowed centralist kingdoms of western Europe to control the elite, the production of public discourse, alongside the shape and permissible uses of a given language. ${ }^{79}$ On the basis, in the $18^{\text {th }}$ and $19^{\text {th }}$ centuries a new norm emerged that a 'proper language' should be accurately 'delimited' from all other (especially 'neighboring') languages and 'adequately developed and cultivated' by (national) scholars and academies that would endow this language-in-making with a 'scientific' grammar and dictionary. ${ }^{80}$ 'Scientific' means here 'large and extensive' and in emulation of such grammars and dictionaries as initially compiled and written for the 'leading' languages, first Latin in the $16^{\text {th }}$ century, and afterward for Italian, French, German or English, especially in the $18^{\text {th }}$ and $19^{\text {th }}$ centuries. ${ }^{81}$

\section{From Policeywissenschaft to Social Engineering}

Most nationalists prefer to stick to the circular logic of national studies rather than face the imminent danger of disenchantment by consenting to the unravelling of their cherished nationalmyths. The myths from which the national master narrative is woven, are patiently and intensively imparted through national systems of education to successive generations. As a result the national master narrative rapidly solidifies and acquires an irresistible allure of the supposedly true past. With so much time, money, emotion and social capital invested in the nation, it is extremely difficult for those

Education and Bilingualism, Vol 62). Clevedon: Multilingual Matters; Pennycook, Alastair. 2010. Language as a Local Practice. Milton Park, Abingdon: Routledge; Sakai, Naoki. 2014. Language as a Countable and the Regime of Translation (pp 35-61). In: Shinji Sato and Neriko Musha Doerr, eds. Rethinking Language and Culture in Japanese Education: Beyond the Standard [translated from the Japanese]. Bristol: Multilingual Matters.

${ }^{78}$ Mühlhäusler, Peter. 1996. Linguistic Ecology: Language Change and Linguistic Imperialism in the Pacific Region (Ser: Politics of Language). London: Routledge, pp 53-54; Musha Doerr, Neriko. 2014. On the Necessity of 'Being Understood:' Rethinking the Ideology of Standardization in Japan (pp 63-81). In: Shinji Sato and Neriko Musha Doerr, eds. Rethinking Language and Culture in Japanese Education: Beyond the Standard [translated from the Japanese]. Bristol: Multilingual Matters, p 67.

${ }^{79}$ Pattanayak 1981, pp 6-21.

${ }^{80}$ Cf Burke, Peter. 2004. Languages and Communities in Early Modern Europe. Cambridge: Cambridge University Press; Kamusella, Tomasz. 2009. The Politics of Language and Nationalism in Modern Central Europe. Basingstoke: Palgrave.

${ }^{81}$ Considine 2008; Considine 2014. 
involved to admit that both nations and national languages are human creations of a recent date. For instance, the Croatian / Yugoslav historian, Nikša_Stančić (1938-), is excellent at relating the fact clearly visibly from the extant sources - that in the first half of the $19^{\text {th }}$ century peasants (or at that time the vast majority of the population) had no interest in the nation, and no understanding of nationalism, while their identity was firmly steeped in religion, their parish and loyalty to the emperor. ${ }^{82}$ Yet, in spite of these facts on the ground, Stančić slavishly sticks to the national dogma's circular logic that the peasants constituted 'pre-national ethnic proto-nations' of Croatians and Serbs, from which the present-day Croatian and Serbian nations developed. ${ }^{83}$ This - perhaps, emotionally, economically and politically motivated - reluctance to relinquish the circular logic of ethnolinguistic nationalism contributes to the lasting vibrancy of this ideology in central Europe, and to the nationally-inflected approach to research. Or perhaps the term 'research' should be put between inverted commas here, given that the overarching aim of such 'national research' is to create, legitimize and maintain national identity; not a dispassionate examination of the past or the present. ${ }^{84}$ Subsequently, graduates of departments of national philology and national history are employed as school teachers and paid reasonably well ${ }^{85}$ for imparting a given nation-state's national identity (as approved by the authorities) to the successive generations of schoolchildren. ${ }^{86}$

In reality, it is none other than a well-oiled state-wide system of mass indoctrination and propaganda. I do not mean this pronouncement as a blanket criticism, but rather as a statement of fact. For better

\footnotetext{
${ }^{82}$ Stančić, Nikša. 2002. Hrvatska nacija i nacionalizam u 19. i 20. stoljeću (Ser: Homines, tempora, loci). Zagreb: Barbat.

${ }^{83}$ I thank Rok Stergar for this excellent illustration of the intellectual phenomenon of scholarly situational blindness (or privileging anachronism), which tends to pop up when some facts from the past are at a variance with a normative ideology of the present day. The latter usually wins, with not much respect for the aforementioned facts and their sociopolitical logic, wed to a specific place and group of people at a given moment in time.

${ }^{84}$ Cf. Hobsbawm 1992, p 12.

${ }^{85}$ Obviously, when universities educate more graduates than needed, a few are unable to find employment in school. It would be interesting to check whether some of those affected may re-invent themselves as 'ethnic entrepreneurs,' utilizing their skills for developing and supporting another or a brand-new nation's history and language. A case that readily comes to mind is that of Yugoslavia. The state splintered into seven separate nation-states, also entailing the breakup of SerboCroatian into four separate national languages. These fissure processes generated an acute demand for specialists who would come up with seven 'properly' fleshed out and justified national master narratives, alongside authoritative dictionaries and grammars for the four new post-Serbo-Croatian languages (cf. Anić, Vladimir. 1991. Rječnik hrvatskoga jezika. Zagreb: Novi Liber and Izdavački centar Cankarjeve založbe za Hrvatsku; Bašanović-Čečović, Jelena et al, eds. 2016. Rječnik crnogorskog narodnog i književnog jezika (Vol 1: A-V) (Ser: Institut za jezik i književnost "Petar II Petrović Njegoš". Rječnici, Vol 8/1). Podgorica: Crnogorska akademija nauka i umjetnosti; Jahić, Dževad A. 2010. Rječnik bosanskog jezika (Vol 1: A - Ć). Sarajevo: Akademija nauka i umjetnosti Bosne i Hercegovine; Vujanić, Milica. 2011. Rečnik srpskoga jezika. Belgrade: Matica Srpska).

${ }^{86}$ Cf. Podstawa 2017.
} 
or worse, people in central Europe (alongside Japan and southeast Asia ${ }^{87}$ ) live in the social reality composed of nations, national languages and nation-states. It is their modernity, as they know it. I am far from postulating that this framework of the region's political, social, cultural and economic organization should be dismantled. The creation of this very framework in the $20^{\text {th }}$-century Europe cost two world wars, millions of casualties and tens of millions of refugees. With ubiquitous surveillance and the staggering stockpiles of weapons of mass destruction, a cost of replacing the national system with a different one would certainly be much higher, including even the extinction of Humankind. Hence, I only propose to see the myth of nation for what it is, a convention adopted as a norm in a given place at a given time, not any 'ultimate truth revealed,' 'reborn' or 'reawakened.' This national convention observed by the majority of central Europe's population now is not the same socio-political convention the region's inhabitants used to observe and act in line with before 1918, let alone in the $10^{\text {th }}$ century. One may discuss and analyze what these earlier conventions were, though one thing is sure, they were non-national. The concept of nation was not part of these prenational conventions of sociopolitical organization. ${ }^{88}$

Ergo, national history and national philology are not disciplines of bona fide research, but respective fields of social engineering (also known as sociotechnics, or social cybernetics). Practitioners of social engineering apply findings of the social sciences in order to achieve pre-planned sociopolitical aims, attempting to shape a given society and reactions of its members in accordance with a specific need or expectation, usually decided upon and financed by the government. An awareness of the use of the social sciences for effecting a desired social change developed rapidly at the turn of the $20^{\text {th }}$ century, both in the West and the early Soviet Union. ${ }^{89}$ Uniquely, in the communist countries, this

\footnotetext{
${ }^{87}$ Kamusella, Tomasz. 2016b. Are Central Europe, and East and Southeast Asia Alike?: The Normative Isomorphism of Language, Nation and State (pp 13-78). In: Kiyoshi Hara and Patrick Heinrich, eds. Standard Norms in Written Languages: Historical and Comparative Studies Between East and West. Tokyo: Joshibi University of Art and Design. https://www.academia.edu/27651466/Are Central Europe and East and Southeast Asia Alike The Normative Isomo rphism of_Language Nation_and_State_Scanned_pp 13-78_.2016. Accessed: Jul 25, 2017.

${ }^{88}$ Cf Malešević, Siniša. 2017. Do National Identities Exist? (pp 1-20). Przestrzeń Spoleczna / Social Space. No 1(13). http://socialspacejournal.eu/13\%20numer/Do\%20national\%20identities\%20exist\%20-\%20Malesevic.pdf. Accessed: Jul 9, 2017.

${ }^{89}$ Cf Hirsch, Francine. 2005. Empire of Nations: Ethnographic Knowledge and the Making of the Soviet Union (Ser: Culture and Society After Socialism). Ithaca NJ: Cornell University Press; Gigiena truda i tekhnika bezopasnosti. 1925. http://www.google.ru/search?q="Социальная+инженерия" \&newwindow=1\&biw=1440\&bih=728\&source=lnt\&tbs=cdr \%3A1\%2Ccd_min\%3A1\%2F1\%2F1900\%2Ccd_max\%3A12\%2F31\%2F1960\&tbm=bks. Accessed: May 26, 2017; Shenton, Herbert N. 1928. The Practical Application of Sociology: A Study of the Scope and Purpose of Applied Sociology. New York: Columbia University Press; Spisy Vedecké. 1922.
} 
awareness was also deployed for the sake of building and destroying languages and their scripts, the process officially known as 'language engineering' (iazykovoe stroitel'stvo). ${ }^{90}$

In some 'enlightened absolutist' monarchies predecessors to social engineering developed during the $18^{\text {th }}$ century across the Holy Roman Empire. The use of legal, economic and administrative measures for the implementation of 'enlightened reforms' (that is, sociopolitical and economic changes) became known as Cameralia Oeconomica in Latin,,${ }^{91}$ or Kameralwissenschaft ${ }^{92}$ and Policeywissenschaft ${ }^{93}$ in German. Social engineering of the present day is all too rarely connected to its $18^{\text {th }}$-century absolutist roots. ${ }^{94}$ However, this continuity proves that a differing and qualified level awareness of the possibility of shaping societies is part and parcel of modernity.

After the Second World War, when technological progress accelerated exponentially, this unprecedented speed of change was paralleled by rapid political events on a global scale, such as decolonization, the proliferation of independent states, and the division of the world into two enemy camps led by the superpowers of the Soviet Union and the United States. Social engineers were in demand then more than ever before, equally in the West, East and across the so-called decolonized 'Third World'. ${ }^{95}$ This need for 'applied social sciences' has continued after the end of the Cold War. With mobile telephony, social media and mass electronic surveillance, practically all of Humanity got

https://books.google.co.uk/books?id=xAcnAQAAIAAJ\&q="sociotechnics"\&dq="sociotechnics"\&hl=en\&sa=X\&redir_es $\mathrm{c}=\mathrm{y}$. Accessed: May 26, 2017.

${ }^{90}$ Asimova, B[ashorat] S[aifitdinova]. 1982. Iazykovoe stroitel'stvo v Tadzhikistane, 1920-1940. Dushanbe: Donish; Isaev, M[agomet] I[zmailovich]. 1979. Iazykovoe stroitel'stvo v SSSR. Protsessy sozdaniia pis'mennosteii narodov SSSR. Moscow: Nauka; Moskalev, A[leksei] A[lekseevich]. 1982. Natsional'no-iazykovoe stroitel'stvo v KNR (80-e gody). Moscow: Nauka.

${ }^{91}$ Cf Gasser, Simon Peter. 1729. Einleitung Zu den Oeconomischen, Politischen und Cameral-Wissenschaften, Worinnen für dieses mal die Oeconomica-Cameralia Von den Domainen-oder Cammer-auch anderns Gütern. Halle: Wysenhaus.

${ }_{92}$ Cf Jung-Stilling, Johann Heinrich. 1780. Daß die Kameralwissenschaft auf einer besonders hiezu gestifteten Hohen Schule vorgetragen werden müsse. Zum Nuzen der Staaten und der Bürger erörtert. Lautern: Kameral Hohe Schule.

${ }^{93}$ Cf Zincken, Georg Heinrich. 1755. Die General-als Special- Land- und Stadtöconomie und Policeywissenschaft. Lepizig: Jacobi.

${ }^{94}$ Cf Foucault, Michel. 1977. Discipline and Punish: The Birth of the Prison [translated from the French by Alan Sheridan]. New York: Pantheon Books.

${ }^{95} \mathrm{Cf}$ Antoniuk, Georgii. 1986. Sotsial'noe proektirovanie i upravlenie obshchestvennym razvitem. Minsk: Nauka i tekhnika; Podgórecki, Adam, ed. 1968. Socjotechnika. Praktyczne zastosowania socjologii. Warsaw: Książka i Wiedza; MacClymer, John F. 1980. War and Welfare: Social Engineering in America, 1890-1925 (Ser: Contributions in American History, Vol 84). Westport CN: Greenwood Press; Saad, Ibrahim. 1980. Social Engineering: The Role of the Schools in Malaysia (Ser: Universiti Kebangsaan Malaysia. Fakulti Sains Kemasyarakatan dan Kemanusiaan, Vol 4). Bangi: Fakulti Sains Kemasyarakatan dan Kemanusiaan, Universiti kebangsaan Malaysia. 
connected and constitute a single 'global village.' 96 The entirely novel situation affords new sets of instruments to social engineers for monitoring and modelling societies even more intensively, while at the same time less perceptibly to those targeted with such measures. Manipulation works best when not noticed by those at whom it is aimed..$^{97}$

Józef Kossecki (1936-2015) was the leading practitioner of social cybernetics in communist Poland. ${ }^{98}$ Following the introduction of martial law in 1981, the military government followed his expert opinions on how to 'manage society' in order to prevent democratization, seen as 'counterrevolutionary. ${ }^{99}$ Nevertheless, in 1989 communism as a system collapsed not only in Poland, but all over the Soviet bloc. Afterward, Kossecki reinvented himself as an aspiring social engineer of Polish nationalism. The proper form of this nationalism, according to Kossecki, should be 'nation-cracy' (nacjokracja), ${ }^{100}$ or the rule of the ethnolinguistically 'pure' Polish nation in Poland. ${ }^{101}$ Kossecki was a convinced social engineer ready to serve the powers that be as long as they paid for his services and research. Following the end of communism he threw in his lot with Polish nationalist groups who, in turn, were happy to tap his expertise. It was a modest Polish way to copy the methods and uses of 'political technologists' (политтехнолог polittekhnolog) who rapidly emerged in Russia during the mid-1990s. ${ }^{102}$ Unlike Soviet social engineers, political technologists do not want to change society in

\footnotetext{
${ }^{96}$ Global Surveillance. 2017. Wikipedia. http://en.wikipedia.org/wiki/Global surveillance\#References. Accessed; Jul 6, 2017; Lule, Jack. 2012. Globalization and Media: Global Village of Babel. Lanham MD: Rowman \& Littlefield; McLuhan, Marshall and Fiore, Quentine. 1963. War and Peace in the Global Village: An Inventory of Some of the Current Spastic Situations That Could Be Eliminated by More Feedforward. New York: Bantam Books.

${ }^{97}$ Cf Etzemüller, Thomas, ed. 2015. Die Ordnung der Moderne. Social Engineering im 20. Jahrhundert (Ser: Histoire, Vol 9). Bielefeld: transcript-Verlag; Jackson, Walter A. 1994. Gunnar Myrdal and America's Conscience: Social Engineering and Racial Liberalism, 1938-1987 (Ser: Fred W. Morrison Series in Southern Studies). Chapel Hill NC: The University of North Carolina Press; Levin, Zeev. 2015. Collectivization and Social Engineering: Soviet Administration and the Jews of Uzbekistan, 1917-1939 (Ser: Eurasian Studies Library, Vol 5). Leiden: Brill; Reznik, Iu M and Shcherbina, V V, eds. 1996. Sotsialnaia inzheneriia. Moscow: MGSU.

${ }^{98}$ Kossecki, Józef. 1975. Cybernetyka społeczna. Warsaw: Państwowe Wydawnictwo Naukowe.

${ }^{99}$ Kossecki, Józef. 1983. Geografia opozycji politycznej w Polsce w latach 1976-1981. Warsaw: Wydawnictwo Ministerstwa Obrony Narodowej.

${ }^{100}$ It appears that the neologism 'nation-cracy' (націократія natsiokrattia) was invented in 1935 by the Ukrainian national activist Mykola Stsibors'kyi (1898-1941) who was active in Paris (Stsibors'kyi, Mykola. 1935. Natsiokrattia. Paris: NA).

${ }^{101}$ Kossecki, Józef. 2014. Naukowe podstawy nacjokratyzmu. Warsaw: HarFOR.

102 Polittekhnolog. 2017. Vikipediia. http://ru.wikipedia.org/wiki/Политтехнолог. Accessed; May 26, 2017.
} 
order to achieve some sociopolitical utopia, such as communism or democracy. Their only role is to make sure that elections are won by candidates, whom the Kremlin handpicked. ${ }^{103}$

Not many scholars reflect squarely on, let alone analyze in depth, this 'applied utility' of the social sciences. I am aware of the Poland-born British sociologist, Stanislav Andreski (Stanisław Andrzejewski, 1919-2007), who touched upon dangers of such 'applied' uses of sociology. ${ }^{104}$ And recently the Polish anthropologist Michał Kowalski (1971-) probed into the 'dirty employment' of social sciences for conducting warfare during the $20^{\text {th }}$ century. ${ }^{105}$

\section{Conclusion}

But what to do with such a clear awareness of the indoctrinating and manipulative character of the already 'standard' school subjects of (national) History and of the National Language? Especially now when these nationalizing subjects are compulsory as a matter of course in Europe and across much of Asia? What is such an awareness good for?

First of all, this awareness lets one understand that the nation (as any non-face-to-face human group) is a construct that is imagined into being on the basis and in agreement with a 'social contract,' as worked out in a given place at a given time. ${ }^{106}$ In other words, this contract is a (usually tacit) agreement of the nation's members to believe that together they constitute a nation, and that they consent to act consistently in line with this belief. Secondly, a clarity on this point unravels the myth of some 'transcendental agency' that supposedly rests in or with the nation. Humans alone are agents

\footnotetext{
${ }^{103}$ Cf Pomerantsev, Peter. 2015. Rise of the Political Technologists: "Nothing Is True and Everything Is Possible". The Huffington Post. 22 May.www.huffingtonpost.co.uk/james-snell/russia-politics_b_6918490.html. Accessed: May 26, 2017.

${ }^{104}$ Andreski, Stanislav. 1972. Social Sciences as Sorcery. London: Deutsch.

${ }^{105}$ Kowalski, Michał W. 2015. Antropolodzy na wojnie. O "brudnej" użyteczności nauk społecznych. Warsaw: Wydawnictwa Uniwersytetu Warszawskiego.

${ }^{106}$ As Rok Stergar rightly remarked, this sentence encapsulates the gist of Ernest Renan's (1823-1892) famous essay 'What is a Nation?' (Renan, Ernest. 1996 [1882]. Qu'est-ce qu'une nation? / What is a Nation? [Translated from the French by Wanda Romer Taylor]. Toronto ONT: Tapir Press). However, I mean this adhortation in a heuristic manner. It is neither a normative statement on how statehood or human groupness should be organized, nor a call for a political action, let alone, to arms.
} 
and take decisions as individuals or as a group. Hence, only these humans as members of a nation enjoy agency, not this nation. The nation is an abstract idea shared by the members (that is, humans) of this 'club' of convenience and conviction. It is a totem under which a human group rallies; a totem visualized as a flag, map, coat-of-arms, dictionary, newspaper, public television, border crossing, or constitution. Abstract ideas have no agency of their own and exist within the human mind. It is their sole 'habitat.' The Ding an sich (noumenon) existing independently of the human mind is an impossibility. Ideas are unable to survive on their own without humans thinking and rethinking them. While doing so humans transmit ideas from one individual to another. An individual or a group of humans use ideas to justify (legitimate) their actions in their own eyes and in the gaze of other people.

If people are aware and consciously in control of their own decisions and what a government may want to decide about a population construed together as a nation, the persons concerned may not that easily succumb to the dictum that 'something' - however awful, or mad - must be done 'in the name of our nation,' that 'the nation or national interest demands it.' In this case the nation is a mask of convenience behind which actual human decision-makers hide. Instead of honestly declaring that it is them taking a specific decision, these decision-makers turn themselves into 'political shamans' who appear to be 'only' mediating between the 'spirit of the nation' and the population concerned. Purporting that the government is a medium specialized in transmitting orders from the 'nation' to its members, and the latter's pleas to the former is a kind of political voodoo. Politicians-cum-shamans playing such a game use the concept of nation to wash their hands of any responsibility for decisions taken. As a result, it is not them but a state's inhabitants, who are compelled to suffer and pay for any negative consequences of such decisions. Should the national make believe work fine, as it usually does, in a moment of commotion and danger, people consider it even as a badge of honor to sacrifice their personal happiness and well-being for the sake of their nation. Rarely does a politician responsible for a disastrous decision join them in this sacrifice.

Thirdly, when people are clear-headed about the fact that the school subjects of (national) History and of the National Language are to indoctrinate them in a rather uncritical belief in and loyalty to 'our Great Nation,' this awareness may at long last strip these school subjects of their supposed 'scientific' character. (National) History and the National Language as imparted at school do not aim at teaching 
the young citizen how to analyze and explain the past and matters linguistic (or sociolinguistic). These two subjects' primary goal is to 'implant' in the youth's heads an approved national master narrative and to train them in the art of how to 'write and speak properly in our language.' As such both school subjects should be recognized as sub-branches of Civics. ${ }^{107}$ Civics being the study of the rights and duties of citizens in a given polity does not conceal its applied character. It is a utilitarian school subject for educating schoolchildren about and training them in the customs, procedures and values of the (national) polity in which they live. Civics offers them hands-on knowledge of state mechanics and of how to be conscious citizens, formulate their opinions effectively, mobilize cocitizens and shape the state's politics within the boundaries of the rule of law (also known as the constitution or social contract).

Nations did not exist two hundred years ago, but nowadays they are extant all around as the overwhelmingly predominant norm of human groupness across the entire globe. The nation is the sole form of such human groupness that is recognized to have the right to its own statehood (also known as the principle of 'national self-determination'). But it is people alone who decide that they want to follow this norm. Similarly, it is them who decide what is a language and what does not count as one. Never does a language or nation make a decision to go to war, choose an alphabet for printing books, or demand the 'ultimate sacrifice of life' from a person. It is always people (that is, 'ethnic

\footnotetext{
${ }^{107}$ To a degree, in Germany the school subject of (national) History is married with and contextualized vis-à-vis Civics in such a manner. Since 1952 the Bundeszentrale für politische Bildung (Federal Agency for Civic Education) has been educating the postwar generations of citizens in (West) Germany in the values of democracy, the rule of law, freedom of speech, and consensual decision-making that steers clear of violence as a legal of preferred instrument of politics (Bundeszentrale für politische Bildung. 2017. Wikipedia. http://de.wikipedia.org/wiki/Bundeszentrale für_politische_Bildung. Accessed; May 29, 2017; Federal Agency for Civic Education. 2017. www.bpb.de/die-bpb/138852/federal-agency-for-civic-education. Accessed; May 29, 2017). The teaching of (national) History at school is conducted in this country within the self-aware framework of Civics. This approach draws tightly at the German philosopher and sociologist Jürgen Habermas's (1929-)concept of Verfassungspatriotismus (constitutional patriotism), which openly declares that the nation (often understood to mean 'state') is a contract or agreement, usually enshrined in a constitution, which is to be observed by all the nation's members (Habermas, Jürgen. 1992. Staatsbürgerschaft und nationale Identität (pp 632-660). In: Jürgen Habermas. Faktizität und Geltung: Beiträge zur Diskurstheorie des Rechts und des demokratischen Rechtsstaats. Frankfurt am Main: Suhrkamp). Civics inculcates the successive post-1945 generations in Germany with a clear-cut awareness of the fact that the school subject of (national) History is part and parcel of the sociopolitical contract on the basis of which the German nation is imagined (constructed). However, even in Germany this awareness of does not extend to the teaching of the National Language. In line with the ideals of the $19^{\text {th }}$-century romantic nationalism the German language continues to appear to (perhaps) most as the 'unanalyzable essence' of the German nation, despite the fact that German in the function of the (or a) national (official) languages is shared with Austria, Belgium, Liechtenstein, Luxembourg and Switzerland.
} 
entrepreneurs' ${ }^{108}$ ) who decide, but employ the smokescreen of 'our nation and language,' as reinforced by school education, in order to make such decisions appear, as though sent down to earth from the 'national heavens,' or decreed by the higher powers that cannot and should not be questioned.

Questioned they must be.

A clear awareness of the constructed and consensual character of nations and languages may yet turn out to be an indispensable instrument for maintaining stable, equitable and prosperous societies. Perhaps, in this novel age of fake news, democracy depends exactly and crucially on this awareness. The citizen should be clear-headed about what she is doing when she accepts one concept of groupness and its organization, or exchanges it for another. None of these choices are neutral or innocent. Each entails a specific set of consequences. However, it is not the nation or national language that make these choices, but humans alone.

Scholars, when finally aware of the national spectacles that schooling and politics put on their nose, they can make a decision to take them off. Intellectual shutters removed, non-national groups cease to be 'irritations' or 'bumps' that need to be hammered out so that they would not mar the evenly homogenous surface of the nation. Such groups can be researched and accorded the dignity of agency, of which the national powers that be try to deprive them . In the recent past of central Europe the majority of non-national groups were peasants who stuck to their village or parish, alongside a specific religion. Another form of such a/non-nationalness came and still comes in the form of borderland (transborder) groups who wish to maintain their own ethnocultural specificity that in no way does not to have be 'against' the nation-state in which they happen to reside. For instance, this is the case of today's Silesians in historical Upper Silesia that straddles the current Czech-Polish border, alongside the phantom frontier of Germany, which after 1945 was removed 300 kilometers westward. The Silesians want to be able to speak their Silesian language and practice their customs without the danger of the state authorities shaming them for this choice and branding as 'national traitors' or a

\footnotetext{
${ }^{108}$ Barth, Fredrik. 1966. Models of Social Organization (Ser: Occasional Paper, Vol 23). London: Royal Anthropological Institute of Great Britain and Ireland, p 17; Brubaker, Rogers. 2002. Ethnicity Without Groups (pp 163-189). Archives Européennes de Sociologie. Vol 43, No 2, p 166-169.
} 
'concealed German menace. ${ }^{109}$ Silesians, depending when they attended school, are perfectly satisfied to write and read in standard Czech, English, German, or Polish, which may or may not be their ethnic languages. For them using several languages is not contrary to logic, as in the case of ethnolinguistic nationalists.

Because the spatial-cum-linguistic partitioning of people into nations is not a product of nature but of the recent past, the vast majority of populace did not identify in this manner in central Europe a century ago. And many still do not, as exemplified by the Catholic Prussians (Prajzové) of the Czech region Hlučín; the Slavophone Muslim Gorani of the confluence of the Albanian, Kosovan and Macedonian boundaries; or a group of Roma who for commercial reasons regularly ply between Bulgaria and Poland, in the former country practicing Islam, while in the latter being good Catholics. ${ }^{110}$ As much as from the normative perspective of nationalism, such groups (or 'subcultures') may be seen as 'unusual,' 'hybrid,' 'non-standard,' or even 'deviant,' nevertheless the sheer organizational and typological variety of human groups was and still is enormous. ${ }^{111}$ The normative proposal that the nation is the sole 'natural' or 'normal' taxonomic form of human groupness is just another myth of nationalism, as readily espoused and popularized by practitioners of national studies.

\footnotetext{
${ }^{109}$ Kaczyński: Zakamuflowaną opcją niemiecką jest śląskość w wydaniu RAŚ. 2011. Polska Times. 6 Apr. www.polskatimes.pl/artykul/389276,kaczynski-zakamuflowana-opcja-niemiecka-jest-slaskosc-w-wydaniu-ras,id,t.html. Accessed: Nov 12, 2017.

${ }^{110}$ Marushiakova, Elena and Popov, Veselin. 2017. Private Communication. 5 Nov. St Andrews: University of St Andrews.

${ }^{111}$ Cf. Pyrah, Robert and Fellerer, Jan. 2015. Redefining 'Sub-Culture:' A New Lens for Understanding Hybrid Cultural Identities in East-Central Europe with a Case Study from Early $20^{\text {th }}$ Century L'viv-Lwów-Lemberg (pp 700-720). Nations and Nationalism. Vol 21, No 4.
} 


\title{
The Fallacy of National Studies
}

\author{
Tomasz Kamusella \\ University of St Andrews
}

\section{References}

Ama, Toshimaro. 2005. Why are the Japanese Non-religious?: Japanese Spirituality: Being NonReligious in a Religious Culture [translated from the Japanese by Michihiro Ama]. Lanham MD: University Press of America.

Andreski, Stanislav. 1972. Social Sciences as Sorcery. London: Deutsch.

Anderson, Benedict. 1983. Imagined Communities: Reflections on the Origin and Spread of Nationalism. London: Verso.

Anić, Vladimir. 1991. Rječnik hrvatskoga jezika. Zagreb: Novi Liber and Izdavački centar Cankarjeve založbe za Hrvatsku.

Antoniuk, Georgii. 1986. Sotsial'noe proektirovanie i upravlenie obshchestvennym razvitem. Minsk: Nauka i tekhnika.

Asimova, B[ashorat] S[aifitdinova]. 1982. Iazykovoe stroitel'stvo v Tadzhikistane, 1920-1940. Dushanbe: Donish.

Baár, Monika. 2013. Historians and Nationalism: East-Central Europe in the Nineteenth Century (Ser: Oxford historical monographs). Oxford: Oxford University Press. 
Barth, Fredrik. 1966. Models of Social Organization (Ser: Occasional Paper, Vol 23). London: Royal Anthropological Institute of Great Britain and Ireland.

Bartulin, Nevenko. 2014. The Racial Idea in the Independent State of Croatia: Origins and Theory (Ser: Central and Eastern Europe: Regional Perspectives in Global Context, Vol 4). Leiden: Brill.

Bašanović-Čečović, Jelena et al, eds. 2016. Rječnik crnogorskog narodnog i književnog jezika (Vol 1: A-V) (Ser: Institut za jezik i književnost "Petar II Petrović Njegoš". Rječnici, Vol 8/1). Podgorica: Crnogorska akademija nauka i umjetnosti.

Baycroft, Timothy and Hopkin, David M, eds. 2012. Folklore and Nationalism in Europe During the Long Nineteenth Century (Ser: National Cultivation of Culture, Vol 4). Leiden: Brill.

Benisz, Adam. 1930. Górny Śląsk w walce o polskość. Katowice: NA.

Bjork, James E. 2011. Neither German nor Pole: Catholicism and National Indifference in a Central European Borderland (Ser: Social History, Popular Culture, and Politics in Germany). Ann Arbor MI: University of Michigan Press.

Blanke, Richard. 2001. Polish Speaking Germans? Language and National Identity Among the Masurians since 1871 (Ser: Ostmitteleuropa in Vergangenheit und Gegenwart, Vol 24). Cologne: Böhlau.

Bobryk, Adam. 2006. Odrodzenie narodowe Polaków w Republice Litewskiej 1987-1997. Toruń: Dom Wydawniczy Duet.

Böckh, Richard. 1866. Die statistische Bedeutung der Volksprache als Kennzeichen der Nationalität (pp 259-402). Zeitschrift für Völkerpsychologie und Sprachwissenschaft. Vol 4. 
Bogdański, Henryk. 1980. Dziennik podróży z lat 1826 i 1827 (Wiedeń-Bratysława-BudapesztZagrzeb-Rijeka-Triest-Lublana-Budapeszt-Przemyśl) (edited by Józef Długosz and Józef Adam Kosiński). Cracow: Wydawnictwo Literackie.

Bonfiglio, Thomas Paul. 2010. Mother Tongues and Nations: The Invention of the Native Speaker (Ser: Trends in Linguistics, Studies and Monographs). Berlin: Walter de Gruyter.

Bonidis, Kyriakos; Palaskas, S and Balabani, K. 2000. Nationalism and Education: The Propagation of the 'Great Idea' of Greek Nationalism Through Education in the European Territories of the Ottoman Empire in the late 19th Century (209-234). In: Nikolaos Terzis, ed. Education in the Balkans: From the Enlightenment to the Founding of the Nation-States (Ser: Education and Pedagogy in Balkan Countries, Vol 2). Thessaloniki: Kyriakidis.

Bradshaw, Brendan. 2016. 'And So Began the Irish Nation': Nationality, National Consciousness and Nationalism in Pre-modern Ireland. London: Routledge.

Breuilly, John. 1993. Nationalism and the State. Manchester: Manchester University Press.

Brubaker, Rogers. 2002. Ethnicity Without Groups (pp 163-189). Archives Européennes de Sociologie. Vol 43, No 2.

Bundeszentrale für politische Bildung. 2017. Wikipedia. http://de.wikipedia.org/wiki/Bundeszentrale_für_politische_Bildung. Accessed; May 29, 2017.

Burke, Peter. 2004. Languages and Communities in Early Modern Europe. Cambridge: Cambridge University Press.

Cetnarowicz, Antoni. 2010. Odrodzenie narodowe w Istrii w latach 1860-1907 (Ser: Studia z Historii XIX wieku, Vol 1). Cracow: Historia Iagellonica. 
Considine, John. 2008. Dictionaries in Early Modern Europe: Lexicography and the Making of Heritage. Cambridge: Cambridge University Press.

Considine, John. 2014. Academy Dictionaries 1600-1800. Cambridge: Cambridge University Press.

Considine, John. 2017. Small Dictionaries and Curiosity: Lexicography and Fieldwork in PostMedieval Europe. Oxford: Oxford University Press.

Cornwall, Mark. 2002. The Last Years of Austria-Hungary: A Multi-national Experiment in Early Twentieth-century Europe. Exeter: University of Exeter Press.

Daskalov, Roumen et al, eds. 2013-2017. Entangled Histories of the Balkans (4 vols) (Ser: Balkan Studies Library, Vols 9, 12, 16, 18.). Leiden: Brill.

Davies, Winifred and Langer, Nils, ed. 2005. Linguistic Purism in the Germanic Languages (Ser: Studia Linguistica Germanica, Vol 75). Berlin: De Gruyter.

De Francesco, Antonino, ed. 2017. In Search of Pre-Classical Antiquity: Rediscovering Ancient Peoples in Mediterranean Europe (19th and 20th c.) (Ser: National Cultivation of Culture, Vol 13). Leiden: Brill.

Die Ergebnisse der Volkszählung vom 31. Dezember 1910 in den im Reichsrate vertretenen Königreichen und Ländern (Vol 1: Die summarischen Ergebnisse der Volkszählung; Ser: Österreichische Statistik, Vol 1, No 1). 2012. Vienna: Bureau der K. u. K. Statistischen Zentralkommission and Gerold in Kommission.

Dominian, Leon. 1917. The Frontiers of Language and Nationality in Europe. New York: Published for the American Geographical Society of New York and Henry Holt; London: Constable. 
Engelking, Anna. 1999. The Natsyas of the Grodno region of Belarus: A Field Study (pp 175-206). Nations and Nationalism. Vol 5, No 2.

Ethnographic Maps of the 19th Century. 2017. http://www.lib.uchicago.edu/e/collections/maps/ethnographic/. Accessed: May 29, 2017.

Etzemüller, Thomas, ed. 2015. Die Ordnung der Moderne. Social Engineering im 20. Jahrhundert (Ser: Histoire, Vol 9). Bielefeld: transcript-Verlag.

Farkas, Ildikó. 2015. Cultural Identity, Nation Building, Modernization: Defining Identity in Japan and East-Central Europe in the $18^{\text {th }}$ and Early $19^{\text {th }}$ Century (pp 51-86). In: Melinda Papp (Pappová), ed. Encounters with Japan: Japanese studies in the Visegrad Four Countries. Budapest: Eötvös University Press (ELTE Faculty of Humanities).

Federal Agency for Civic Education. 2017. www.bpb.de/die-bpb/138852/federal-agency-for-civiceducation. Accessed; May 29, 2017.

Fellerer, Jan. 2005. Mehrsprachigkeit im galizischen Verwaltungswesen (1772-1914). Eine historisch-soziolinguistische Studie zum Polnischen und Ruthenischen (Ukrainischen) (Ser: Bausteine zur Slavischen Philologie und Kulturgeschichte, Series A: Neue Folge, Slavistische Forschungen, Vol 46). Cologne: Böhlau.

Foucault, Michel. 1977. Discipline and Punish: The Birth of the Prison [translated from the French by Alan Sheridan]. New York: Pantheon Books.

Gal, Susan. 2011. Polyglot Nationalism: Alternative Perspectives on Language in $19^{\text {th }}$ Century Hungary (pp 31-54). Langage et société. No 2 (136). 
Gasser, Simon Peter. 1729. Einleitung Zu den Oeconomischen, Politischen und CameralWissenschaften, Worinnen für dieses mal die Oeconomica-Cameralia Von den Domainen-oder Cammer-auch anderns Gütern. Halle: Wysenhaus.

Gellner, Ernest. 1983. Nations and Nationalism. Oxford: Blackwell.

Gibson, Catherine. 2016. Borderlands Between History and Memory: Latgale's Palimpsestuous Past in Contemporary Latvia (Ser: Politics and Society in the Baltic Sea Region). Tartu: Tartu University Press.

Gibson, Catherine. 2017. 19th Century Ethnographic Maps of the North-West Russian Empire: Estonia, Latvia, Lithuania, Belarus, Poland. historicalbalticmaps.com/project-type/ethnographicmaps/. Accessed: May 29, 2017.

Gigiena truda i tekhnika bezopasnosti. 1925.

http://www.google.ru/search?q="Социальная +инженерия"\&newwindow=1\&biw=1440\&bih=728\& source $=\ln$ t\&tbs $=\mathrm{cdr} \% 3 \mathrm{~A} 1 \% 2 \mathrm{Ccd} \min \% 3 \mathrm{~A} 1 \% 2 \mathrm{~F} 1 \% 2 \mathrm{~F} 1900 \% 2 \mathrm{Ccd} \max \% 3 \mathrm{~A} 12 \% 2 \mathrm{~F} 31 \% 2 \mathrm{~F} 1960 \& \mathrm{t}$ $\underline{b m=b k s}$. Accessed: May 26, 2017.

Global Surveillance. 2017. Wikipedia. http://en.wikipedia.org/wiki/Global_surveillance\#References. Accessed; Jul 6, 2017.

Goble, Luke J. 2007 [PhD dissertation]. Indians and the National Unconscious: Discourses of Nationalism and Democracy in the United States and Bolivia, 1780-1850. Buffalo NY: State University of New York at Buffalo.

Göderle, Wolfgang. 2016a. Zensus und Ethnizität. Zur Herstellung von Wissen über soziale Wirklichkeiten im Habsburgerreich zwischen 1848 und 1910. Göttingen: Wallstein Verlag. 
Göderle, Wolfgang. 2016b. Administration, Science, and the State: The 1869 Population Census in Austria-Hungary (pp 61-88). Austrian History Yearbook. Vol 47.

Goffart, Walter. 2003. Historical Atlases: The First Three Hundred Years, 1570-1870. Chicago IL: University of Chicago Press.

Greenberg, Marc L. 2011. The Illyrian Movement: A Croatian Vision of South Slavic Unity (pp 364380). In: Joshua Fishman and Ofelia García, eds. Handbook of Language and Ethnic Identity (Vol 2: The Success-Failure Continuum in Language and Ethnic Identity Efforts). Oxford: Oxford University Press.

Greenberg, Robert D. 2004. Language and Identity in the Balkans: Serbo-Croatian and Its Disintegration. Oxford: Oxford University Press.

Greenfeld, Liah. 1992. Nationalism: Five Roads to Modernity. Cambridge MA: Harvard University Press.

Grdina, Igor. 2016. Tajna zgodovina. Reporter. 22 May. http://twitter.com/revijareporter/status/734621095362433024. Accessed: Jun 12, 2016.

Grimm, Jacob and Grimm Wilhelm. 1985-1989. Brüder Grimm Volkslieder. Aus der Handschriftensammlung der Universitätsbibliothek Marburg. Marburg: Elwert.

Habermas, Jürgen. 1992. Staatsbürgerschaft und nationale Identität (pp 632-660). In: Jürgen Habermas. Faktizität und Geltung: Beiträge zur Diskurstheorie des Rechts und des demokratischen Rechtsstaats. Frankfurt am Main: Suhrkamp.

Heinrich, Patrick. 2012. The Making of Monolingual Japan: Language Ideology and Japanese Modernity. Bristol: Multilingual Matters. 
Henselius, Godofredus [Hensel, Gottfried]. 1741. Synopsis Universae Philologiae. Nurmeberg: In commissis apud Herdes Homannionos (NB: The maps of the Americas, Europe, Asia and Africa at the book's end: http://en.wikipedia.org/wiki/File:Hensel_1741_4maps.jpg and http://books.google.co.uk/books?id=Dj4xABSH-

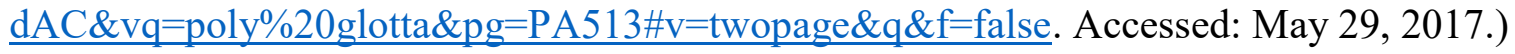

Herder, Johann Gottfried. 1800. Outlines of a Philosophy of the History of Man [translated from the German of John Godfrey Herder, by T. Churchill]. London: Printed for J. Johnson, by Luke Hansard.

Hirsch, Francine. 2005. Empire of Nations: Ethnographic Knowledge and the Making of the Soviet Union (Ser: Culture and Society After Socialism). Ithaca NJ: Cornell University Press.

Hirschi, Caspar. 2012. The Origins of Nationalism: An Alternative History from Ancient Rome to Early Modern Germany. Cambridge: Cambridge University Press.

Hobsbawm, Eric J. 1992. Nations and Nationalism since 1780. Cambridge: Cambridge University Press.

Hroch, Miroslav. 1985. Social Preconditions of National Revival in Europe: A Comparative Analysis of the Social Composition of Patriotic Groups Among the Smaller European Nations. Cambridge: Cambridge University Press.

Hrushevsky, Michael. 1965. The Traditional Scheme of 'Russian' History and the Problem of a Rational Organization of the History of the East Slavs (Ser: Slavistica). Winnipeg: Ukrainian Free Academy of Sciences and Ukrainian Canadian University Students' Union.

Isaev, M[agomet] I[zmailovich]. 1979. Iazykovoe stroitel'stvo v SSSR. Protsessy sozdaniia pis'mennosteii narodov SSSR. Moscow: Nauka. 
Jackson, Walter A. 1994. Gunnar Myrdal and America's Conscience: Social Engineering and Racial Liberalism, 1938-1987 (Ser: Fred W. Morrison Series in Southern Studies). Chapel Hill NC: The University of North Carolina Press.

Jacobson, H F. 1856. Staat und Kirche (pp 420-489). In: Julius Weiske, ed. Rechtslexikon für juristen aller teutschen Staaten (Vol 10). Leipzig: Wigand.

Jahić, Dževad A. 2010. Rječnik bosanskog jezika (Vol 1: A - Ć). Sarajevo: Akademija nauka i umjetnosti Bosne i Hercegovine.

Jankowiak, Mirosław. 2016. Funkcjonowanie języka łatgalskiego w sytuacji wielokulturowości i wielojęzyczności (pp 273-296). Zeszyty Łużyckie. Vol 50.

Jensen, Lotte, ed. 2016. The Roots of Nationalism: National Identity Formation in Early Modern Europe, 1600-1815 (Ser: Heritage and Memory Studies, Vol 1). Amsterdam: Amsterdam University Press.

Judson, Pieter M. 2006. Guardians of the Nation: Activists on the Language Frontiers of Imperial Austria. Cambridge MA: Harvard University Press.

Judson, Pieter M. 2016. The Habsburg Empire: A New History. Cambridge MA: Harvard University Press.

Jungmann, Josef. 1835-1839. Slownjk česko-německý (5 vols). Prague: Pomocj Českého Museum.

Jung-Stilling, Johann Heinrich. 1780. Daß die Kameralwissenschaft auf einer besonders hiezu gestifteten Hohen Schule vorgetragen werden müsse. Zum Nuzen der Staaten und der Bürger erörtert. Lautern: Kameral Hohe Schule. 
Kaczmarek, Mirella. 2012. Glosariusz - książka zakazana przez Urząd Marszałkowski. Nowa Trybuna Opolska. 15 Jan. www.nto.pl/wiadomosci/opolskie/art/4475037,glosariusz-ksiazkazakazana-przez-urzad-marszalkowski,id,t.html. Accessed: Jun 1, 2017.

Kaczyński: Zakamuflowaną opcją niemiecką jest śląskość w wydaniu RAŚ. 2011. Polska Times. 6 Apr. www.polskatimes.p1/artyku1/389276,kaczynski-zakamuflowana-opcja-niemiecka-jest-slaskoscw-wydaniu-ras,id,t.html. Accessed: Nov 12, 2017.

Kadare, Ismail. 1997. The File on H. New York: Arcade Publishing.

Kamusella, Tomasz. 2001. Language as an Instrument of Nationalism in Central Europe (pp 235252). Nations and Nationalism. Vol 7, No 2.

Kamusella, Tomasz. 2004. On the Similarity Between the Concepts of Nation and Language (pp 107112). Canadian Review of Studies in Nationalism. Vol 31.

Kamusella, Tomasz. 2007. Silesia and Central European Nationalisms: The Emergence of National and Ethnic Groups in Prussian Silesia and Austrian Silesia, 1848-1918 (Ser: Central European Studies). West Lafayette IN: Purdue University Press.

Kamusella, Tomasz. 2009. The Politics of Language and Nationalism in Modern Central Europe. Basingstoke: Palgrave.

Kamusella, Tomasz. 2010. Philologists: Scholars or, Perhaps, Politicians? Review: D L Hoyt and K Oslund, eds. The Study of Language and the Politics of Community in Global Context (pp 327-334). Polish Sociological Review. No 3 (171).

Kamusella, Tomasz. 2016a. The History of the Normative Opposition of 'Language versus Dialect:' From Its Graeco-Latin Origin to Central Europe's Ethnolinguistic Nation-States (pp 164-188). 
Colloquia Humanistica. Vol 5.

http://ispan.waw.pl/journals/index.php/ch/article/view/ch.2016.011/2342. Accessed: May 29, 2017.

Kamusella, Tomasz. 2016b. Are Central Europe, and East and Southeast Asia Alike?: The Normative Isomorphism of Language, Nation and State (pp 13-78). In: Kiyoshi Hara and Patrick Heinrich, eds. Standard Norms in Written Languages: Historical and Comparative Studies Between East and West. Tokyo: Joshibi University of Art and Design.

https://www.academia.edu/27651466/Are_Central_Europe_and_East_and_Southeast_Asia_Alike_Th e_Normative_Isomorphism_of_Language_Nation_and_State_Scanned_pp 13-78_2016. Accessed: Jul 25, 2017.

Kamusella, Tomasz; Bjork, James; Wilson, Timothy and Novikov, Anna, eds. 2016. Creating Nationality in Central Europe, 1880-1950: Modernity, Violence and (Be)Longing in Upper Silesia (Ser: Routledge Studies in the History of Russia and Eastern Europe, Vol 25). London: Routledge.

King, Jeremy. 2005. Budweisers into Czechs and Germans: A Local History of Bohemian Politics, 1848-1948. Princeton NJ: Princeton University Press.

Kitromilides, Paschalis M. 1989. 'Imagined Communities' and the Origins of the National Question in the Balkans (pp 149-194). European History Quarterly. Vol 19, No 2.

Kizwalter, Tomasz. 1999. O nowoczesności narodu. Przypadek Polski. Warsaw: Wydanictwo Naukowe Semper.

Kloss, Heinz. 1967. 'Abstand Languages' and 'Ausbau Languages' (pp 29-41). Anthropological Linguistics. Vol 9, No 7.

Kochman, Stanisław. 2004. On nie reprezentuje uniwersytetu (p 14). Nowa Trybuna Opolska. 14 May. 
Kohut, Zenon E. 1994. History as a Battleground: Russian-Ukrainian Relations and Historical Consciousness in Contemporary Ukraine (pp123-146). In: S Frederick Starr, ed. The Legacy of History in Russia and the New States of Eurasia (Ser: International Politics of Eurasia, Vol 1). Armonk NY: M E Sharpe.

Kolberg, Oskar. 1857-1907. Lud. Jego zwyczaje, sposób życia, mowa, podania, przysłowia, obrzędy, gusła, zabawy, pieśni, muzyka i tańce. Warsaw: W drukarni Jana Jaworskiego.

Kollár, Jan. 1832. Sláwy Dcera. Lyricko-epická báseň w pěti zpěwjch. Pest: Trattner a Károli. http://books.google.co.uk/books?id=k8gGAAAAQAAJ\&printsec=frontcover\&dq=Sláwy+dcera\&hl= en\&sa=X\&ved=0ahUKEwjcuoui9JXUAhWMIcAKHcbnAHIQ6AEIJDAA\#v=onepage\&q=Sláwy dcera\&f=false. Accessed: May 29, 2017.

Korowicz, Marek Stanisław. 1938. Górnośląska ochrona mniejszości, 1922-1937, na tle stosunków narodowościowych, z 3 mapami (Ser: Pamiętnik Instytutu Śląskiego, Vol 7). Katowice: Wydawnictwa Instytutu Śląskiego (distributed by Nasza Księgarnia, Warsaw).

Kosi, Jernej. 2013. Kako je nastal slovenski narod. Začetki slovenskega nacionalnega gibanja v prvi polovici 19. stoletja (Ser: Zbirka Naprej!). Ljubljana: Sophia.

Kossecki, Józef. 1975. Cybernetyka społeczna. Warsaw: Państwowe Wydawnictwo Naukowe.

Kossecki, Józef. 1983. Geografia opozycji politycznej w Polsce w latach 1976-1981. Warsaw: Wydawnictwo Ministerstwa Obrony Narodowej.

Kossecki, Józef. 2014. Naukowe podstawy nacjokratyzmu. Warsaw: HarFOR.

Kowalski, Michał W. 2015. Antropolodzy na wojnie. O "brudnej" użyteczności nauk społecznych. Warsaw: Wydawnictwa Uniwersytetu Warszawskiego. 
Kumar, Ran Vijoy. 1989. Role of the Middle Class in Nationalist Movement, 1912-1947. New Delhi: Commonwealth Publishers.

Kurze Beschreibung der in Europa befintlichen Völckern und Ihren Aigenschaften ('Völkertafel'). c 1725 [2017]. Wikipedia. https://de.wikipedia.org/wiki/Datei:Völkertafel.jpg. Accessed: May 29, 2017.

Leersen, Joep. 2007. National Thought in Europe: A Cultural History. Amsterdam: Amsterdam University Press.

Levin, Zeev. 2015. Collectivization and Social Engineering: Soviet Administration and the Jews of Uzbekistan, 1917-1939 (Ser: Eurasian Studies Library, Vol 5). Leiden: Brill.

Lewicki, Anatol. 1947. Zarys historii Polski (Vol 1: Do r. 1795). London: Obris

Lie, John. 2001. Multiethnic Japan. Cambridge MA: Harvard University Press.

Linde, Samuel. 1854-1860. Słownik języka polskiego przez M. Samuela Bogumiła Linde. Lwów [Lviv]: W Drukarni Zakładu Ossolińskich.

Linek, Bernard. 2013. Biskupitz (Biskupice) und Borsigwerk. Soziale Modernisierungswege in Oberschlesien in der zweiten Hälfte des 19. Jahrhunderts (pp 61-77). In: Lutz Budraß. ed. Industrialisierung und Nationalisierung. Fallstudien zur Geschichte des oberschlesischen Industriereviers im 19. und 20. Jahrhundert (Ser: Veröffentlichungen zur Kultur und Geschichte des östlichen Europa, Vol 40). Essen: Klartext.

Łuczewski, Michał. 2012. Odwieczny naród. Polak i katolik w Żmiącej (Ser: Monografie Fundacji na Rzecz Nauki Polskiej). Toruń: Wydawnictwo Naukowe Uniwersytetu Mikołaja Kopernika. 
Lule, Jack. 2012. Globalization and Media: Global Village of Babel. Lanham MD: Rowman \& Littlefield.

MacClymer, John F. 1980. War and Welfare: Social Engineering in America, 1890-1925 (Ser:

Contributions in American History, Vol 84). Westport CN: Greenwood Press.

Mackridge, Peter. 2010. Language and National Identity in Greece, 1766-1976. Oxford: Oxford University Press.

McLuhan, Marshall and Fiore, Quentine. 1963. War and Peace in the Global Village: An Inventory of Some of the Current Spastic Situations That Could Be Eliminated by More Feedforward. New York: Bantam Books.

McVeigh, Brian J. 2006. Nationalisms of Japan: Managing and Mystifying Identity. Lanham MD: Rowman \& Littlefield.

Makoni, Sinfree and Pennycook, Alastair. 2007. Disinventing and Reconstituting Languages (pp 141). In: Sinfree Makoni and Alastair Pennycook, eds. Disinventing and Reconstituting Languages (Ser: Bilingual Education and Bilingualism, Vol 62). Clevedon: Multilingual Matters.

Malešević, Siniša. 2017. Do National Identities Exist? (pp 1-20). Przestrzeń Społeczna / Social Space. No 1(13).

http://socialspacejournal.eu/13\%20numer/Do\%20national $\% 20$ identities $\% 20$ exist $\% 20$ \%20Malesevic.pdf. Accessed: Jul 9, 2017.

Manela, Erez. 2007. The Wilsonian Moment: Self-Determination and the International Origins of Anticolonial Nationalism. Oxford: Oxford University Press.

Markus, Tomislav. 2010. The Serbian Question in Croatian Politics, 1848-1918 (pp 165-188). Review of Croatian History. Vol 6, No 1. hrcak.srce.hr/file/100788. Accessed: Jul 26, 2017. 
Martin, Bernd. 1990. The German Role in the Modernization of Japan: The Pitfall of Blind Acculturation [translated from the German by Peter Wetzler] (pp 77-88). Oriens Extremus. Vol 33, No 1.

Marushiakova, Elena and Popov, Veselin. 2017. Private Communication. 5 Nov. St Andrews: University of St Andrews.

Mârza, Radu. 2008. The History of Romanian Slavic Studies: From the Beginnings until the First World War [translated from the Romanian By Leonard Ciocan]. Cluj-Napoca: Romanian Academy and Center for Transylvanian Studies.

Masaryk, Tomáš Garrigue. 1936 [1925]. Světová revoluce: Za války a ve válce 1914-1918. Světová revoluce: Za války a ve válce 1914-1918. Prague: Čin a Orbis.

kramerius4.nkp.cz/search/i.jsp?pid=uuid:51ce79a0-1b70-11e3-9319-005056827e51\#monographpage_uuid:b01653f0-3625-11e3-b79f-5ef3fc9bb22f. Accessed: Jul 9, 2017.

Merchiers, Ingrid. 2007. Cultural Nationalism in the South Slav Habsburg Lands in the Early Nineteenth Century: The Scholary Network of Jernej Kopitar (1780-1844) (Ser: Slavistische Beiträge, Vol 455). Munich: Sagner.

Minnich, Robert G. 1988. Govoriti slovensko - biti Slovenec. Primerjava med vlogo slovenskih verbalnih kod kot nosilcev kolektivne identitete v Kanalski dolini/Val Canale v Italiji, in Ziljski dolini/Galital v Avstriji. Trieste: Slovenski raziskovalni inštitut / Istituto sloveno di ricerche / Slovene research institute.

Morariu, Leca. 1937. Maiorescu și neologismul. Cernăuți (Chernivtsi): Tiparul Glasul Bucovinci.

Moritsch, Andreas. 1991. Der nationale Differenzierungsprozess am Beispiel 
ländlicher Gemeinden Südkärnens (pp 44-92). In: Andreas Moritsch, ed. Vom Ethnos zur Nationalität. Der nationale Differenzierungsprozeß am Beispiel ausgewählter Orte in Kärnten und im Burgenland (Ser: Wiener Beiträge zur Geschichte der Neuzeit, Vol 18). Vienna: Verlag für Geschichte und Politik and Munich: R Oldenburg Verlag.

Moskalev, A[leksei] A[lekseevich]. 1982. Natsional'no-iazykovoe stroitel'stvo v KNR (80-e gody). Moscow: Nauka.

Mróz, Maciej. 2003. Katolicyzm na pograniczu. Kościół katolicki wobec kwestii ukraińskiej i białoruskiej w Polsce w latach 1918-1925. Toruń: Wydawnictwo Adam Marszałek,

Mühlhäusler, Peter. 1996. Linguistic Ecology: Language Change and Linguistic Imperialism in the Pacific Region (Ser: Politics of Language). London: Routledge.

Musha Doerr, Neriko. 2014. On the Necessity of 'Being Understood:' Rethinking the Ideology of Standardization in Japan (pp 63-81). In: Shinji Sato and Neriko Musha Doerr, eds. Rethinking Language and Culture in Japanese Education: Beyond the Standard [translated from the Japanese]. Bristol: Multilingual Matters.

Neuhaus, Helmut. 2002. Konfessionalisierung und Territorialstaat (pp 343-362). In: Gerhard Müller, Horst Weigelt and Wolfgang Zorn, eds. Handbuch der Geschichte der evangelischen Kirche in Bayern (Vol 1: Von den Anfängen des Christentums bis zum Ende des 18. Jh). St. Ottilien: EOSVerlag.

Pallas, Peter Simon. 1786-1789. Sravnitel'nye slovari vsech iazykov i narechii / Linguarum totius orbis vocabularia comparative. St Petersburg: Schnoor.

Pattanayak, D P. 1981. Multilingualism and Mother-Tongue Education. Delhi: Oxford University Press. 
Pennycook, Alastair. 2010. Language as a Local Practice. Milton Park, Abingdon: Routledge.

Petranović, Branko. 2002. The Yugoslav Experience of Serbian National Integration (Ser: East European Monographs, Vol 586). Boulder CO: East European Monographs (distributed by Columbia University Press, New York).

Podgórecki, Adam, ed. 1968. Socjotechnika. Praktyczne zastosowania socjologii. Warsaw: Książka i Wiedza.

Podstawa programowa - Historia - klasy IV-VIII. 2017. Warsaw: Ministerstwo Edukacji Narodowej. https://men.gov.pl/wp-content/.../11/podstawa-programowa-historia-klasy-iv-viii.pdf. Accessed: May 26, 2017.

Polittekhnolog. 2017. Vikipediia. http://ru.wikipedia.org/wiki/Политтехнолог. Accessed; May 26, 2017.

Pomerantsev, Peter. 2015. Rise of the Political Technologists: "Nothing Is True and Everything Is Possible". The Huffington Post. 22 May.www.huffingtonpost.co.uk/james-snell/russiapolitics_b_6918490.html. Accessed: may 26, 2017.

Preschern, Franz [=Prešeren, France]. 1833. Sängers Klage. Illyrisches Blatt. Vol 7, No 24. 15 Jun.

Preston, Dennis R. 1989. Perceptual Dialectology: Nonlinguists' Views of Areal Linguistics (Ser: Topics in Sociolinguistics, Vol 7). Berlin: De Gruyter Mouton.

Pyrah, Robert and Fellerer, Jan. 2015. Redefining 'Sub-Culture:' A New Lens for Understanding Hybrid Cultural Identities in East-Central Europe with a Case Study from Early $20^{\text {th }}$ Century L'vivLwów-Lemberg (pp 700-720). Nations and Nationalism. Vol 21, No 4. 
Renan, Ernest. 1996 [1882]. Qu'est-ce qu'une nation? / What is a Nation? [Translated from the French by Wanda Romer Taylor]. Toronto ONT: Tapir Press.

Report of the Delegates to the International Statistical Congress Held at St Petersburg in August, 1872 (Ser: US House Documents: 43rd Congress, 1st Session, Vol 17, No 289). 1875. Washington: Government Printing Office. http://books.google.co.uk/books?id=J$\underline{\text { sxAQAAMAAJ\&printsec }=\text { frontcover } \& d q=\text { international }+ \text { statistical }+ \text { congress }+1872 \& h l=e n \& s a=X \& v}$ $\underline{\text { ed=0ahUKEwjVu6mg pfUAhVGKcAKHfeKDMQQ6AEIJDAA\#v=onepage\&q=international } \% 20 \text { st }}$ atistical\%20congress \%201872\&f=false. Accessed: May 30, 2017.

Reznik, Iu M and Shcherbina, V V, eds. 1996. Sotsialnaia inzheneriia. Moscow: MGSU.

Rodkiewicz, Witold. 1998. Russian Nationality Policy in the Western Provinces of the Empire (18631905). Lublin: Scientific Society of Lublin.

Saad, Ibrahim. 1980. Social Engineering: The Role of the Schools in Malaysia (Ser: Universiti Kebangsaan Malaysia. Fakulti Sains Kemasyarakatan dan Kemanusiaan, Vol 4). Bangi: Fakulti Sains Kemasyarakatan dan Kemanusiaan, Universiti kebangsaan Malaysia.

Sakai, Naoki. 2014. Language as a Countable and the Regime of Translation (pp 35-61). In: Shinji Sato and Neriko Musha Doerr, eds. Rethinking Language and Culture in Japanese Education: Beyond the Standard [translated from the Japanese]. Bristol: Multilingual Matters.

Senft, Stanisław and Drobek, Wiesław. 2004. W sprawie wypowiedzi prasowych dr Tomasza Kamuselli. Śląsk Opolski. No 2 (51).

Shenton, Herbert N. 1928. The Practical Application of Sociology: A Study of the Scope and Purpose of Applied Sociology. New York: Columbia University Press. 
Shinto \& Buddhism. 2017. https://www.japanspecialist.co.uk/travel-tips/shinto-buddhism/. Accessed: Jun 1, 2017.

Sieroszewski, Wacław. 1957. Zamorski diabeł. Jan-Gui-Tzy. Warsaw: Ludowa Spółdzielnia Wydawnicza.

Šmahel, František. 1971. Idea národa v husitských Čechách. České Budějovice: Růže.

Spisy Vedecké. 1922.

https://books.google.co.uk/books?id=xAcnAQAAIAAJ\&q="sociotechnics"\&dq="sociotechnics"\&hl $=$ en\&sa=X\&redir_esc=y. Accessed: May 26, 2017.

Stančić, Nikša. 2002. Hrvatska nacija i nacionalizam u 19. i 20. stoljeću (Ser: Homines, tempora, loci). Zagreb: Barbat

Stauter-Halsted, Keely. 2004. The Nation in the Village: The Genesis of Peasant National Identity in Austrian Poland, 1848-1914. Ithaca NY: Cornell University Press.

Stefanović, Vuk / Stephansohn, Wolf / Lupi, Stephani F [=Karadžić, Vuk]. 1818. Srpski rječnik isšolkovan njemačkim i latinskim riječma / Serbisch-Deutsch-Lateinisches Wörterbuch / Lexicon Serbiou-Germanico-Latinum. Vienna: Gedruckt bei den P.P. Armeniern.

Stergar, Rok. 2017. Illyrian Autochthonism and the Beginnings of the South Slav Nationalisms in the West Balkans (pp 96-118). In: Antonino De Francesco, ed. In Search of Pre-Classical Antiquity: Rediscovering Ancient Peoples in Mediterranean Europe (19th and 20th c.) (Ser: National Cultivation of Culture, Vol 13). Leiden: Brill.

Štih, Peter. 2010. The Middle Ages Between the Eastern Alps and the Northern Adriatic: Select Papers on Slovene Historiography and Medieval History (Ser: East Central and Eastern Europe in the Middle Ages, 450-1450, Vol 11). Leiden: Brill. 
Stral'tsoŭ, B V. 1967. V bor'be za Sovetskuiu vlast'. Minsk: Beralus'.

Struve, Kai. 2011. Bauern und ukrainische Nation in der Habsburgermonarchie und im Zarenreich (pp 159-173). In: Kappeler, Andreas, ed. Die Ukraine. Prozesse der Nationsbildung. Cologne: Böhlau.

https://www.academia.edu/30734129/Bauern und ukrainische Nation in der Habsburgermonarchi e und im Zarenreich. Accessed: Jul 26, 2017.

Stsibors'kyi, Mykola. 1935. Natsiokrattia. Paris: NA.

Sugimoto, Yoshio and Mouer, Ross. 2009. Cross-Currents in the Study of Japanese Society (pp 1-38). Yoshio Sugimoto and Ross Mouer, ed. Constructs For Understanding Japan (Ser: Japanese Studies). Abingdon: Routledge.

Sundhaußen, Holm. 1973. Der Einfluß Herderschen Ideen auf die Nationsbildung bei den Völkern der Habsburger Monarchie (Ser: Buchreihe der Südostdeutschen Historischen Kommission, Vol 27). Munich: R Oldenburg Verlag.

Szczepanik, Marek. 2004. Wizje pana doktora. Rzeczpospolita. No 107, 8 May. archiwum.rp.pl/artykul/486002-Wizje-pana-doktora.html. Accessed: Jul 26, 2017.

Thaden, Edward, ed. 1981. Russification in the Baltic Provinces and Finland, 1855-1914. Princeton NJ: Princeton University Press.

The National Question in Ethiopia: Proletarian Internationalism or Bourgeois Nationalism? 1976. Toronto: Norman Bethune Institute.

Thomas, George. 1996. Towards a History of Modern Czech Purism: The Problem of Covert Germanisms (pp 401-420). The Slavonic and East European Review. Vol 74, No 3. 
Thompson Manning, Roberta. 1982. The Zemstvo and Politics, 1864-1914 (pp 133-176). In: Terence Emmons and Wayne S. Vucinich, eds. The Zemstvo in Russia: An Experiment in Local SelfGovernment. Cambridge Cambridge University Press.

Trapl, Miroslav. 1977. České národní obrození na Moravěv době předbřeznové a v revolučních letech 1848-1849. Brno: Blok.

Trudgill, Peter. 2003. A Glossary of Sociolinguistics. Edinburgh: Edinburgh University Press.

Varga, Balint. 2014. Multilingualism in Urban Hungary, 1880-1910 (pp 965-980). Nationalities Papers. Vol 42. No 6.

Vujanić, Milica. 2011. Rečnik srpskoga jezika. Belgrade: Matica Srpska.

Watenpaugh, Keith David. 2006. Being Modern in the Middle East: Revolution, Nationalism, Colonialism, and the Arab Middle Class. Princeton NJ: Princeton University Press.

Wawn, Andrew, eds 2007. Constructing Nations, Reconstructing Myth: Essays in Honour of $T$ A Shippey (Ser: Making the Middle Ages, Vol 9). Turnhout: Brepols.

Weber, Eugen. 1976. Peasants into Frenchmen: The Modernization of Rural France, 1870-1914. Stanford CA: Stanford University Press.

Wexler, Paul N. 1974. Purism and Language: A Study in Modern Ukrainian and Belorussian Nationalism (1840-1967). Bloomington IN: Indiana University.

White, George W. 2000. Nationalism and Territory: Constructing Group Identity in Southeastern Europe (Ser: Geographical Perspectives on the Human Past). Lanham MD: Rowman \& Littlefield. 
Wilczy bilet. 2017. Wikipedia. http://pl.wikipedia.org/wiki/Wilczy_bilet. Accessed: May 31, 2017.

Woolf, Alex. 2009. Systems of Government Democracy. London: Evans.

Yeounsuk, Lee. 2010. The Ideology of Kokugo Nationalizing Language in Modern Japan [translated from the Japanese by Maki Hirano Hubbard]. Honolulu HI: University of Hawai'i Press.

Zahra, Tara. 2011. Kidnapped Souls National Indifference and the Battle for Children in the Bohemian Lands, 1900-1948. Ithaca NY: Cornell University Press.

Zajc, Marko. 2008. Gdje slovensko prestaje, a hrvatsko počinje. Slovensko-hrvatska granica u 19. i početkom 20. stoljeća (translated from the Slovenian to Croatian by Anita Peti-Stantić, Sanja Slukan and Miroslav Gradečak). Zagreb: Srednja Europa.

Zincken, Georg Heinrich. 1755. Die General-als Special- Land- und Stadtöconomie und Policeywissenschaft. Lepizig: Jacobi. 